\title{
NÁLEZY HLINENÝCH FAJOK ZO SPIŠA
}

\author{
Mário Bielich - Marián Soják
}

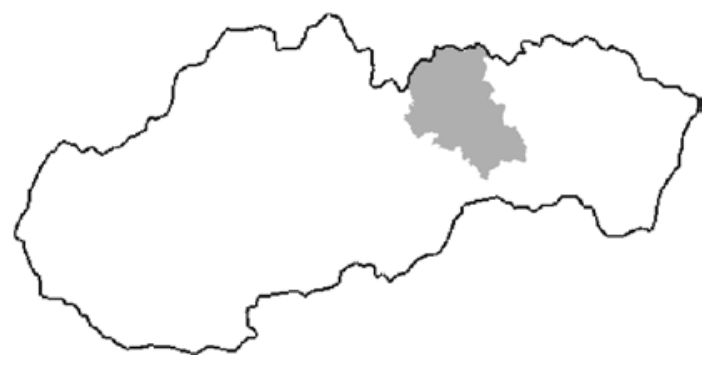

DOI: https://doi.org/10.31577/szausav.2019.65.9

Key words: Spiš Region, Modern Times, $17^{\text {th }}$ to $20^{\text {th }}$ Century, Clav Pipe

\section{Clay Pipes from Spiš Region}

The contribution was created by processing the collection of clay pipes finds from the depository of the Spiš branch of the Archaeological Institute in Nitra. In the present text, 127 fragments of clay pipes are discovered, which were discovered on Spiš. Clay pipes are described on the basis of a formalized description that we used in 2013 (Čurný/Šimčík/ Bielich 2013). In the studied ensemble are dominated pipes from $17^{\text {th }}-18^{\text {th }}$ century. Hungarian production. In the Spiš Castle was discovered clay pipes manufacture in the 70 s of the $20^{\text {th }}$ century by A. Vallasek (1983). Some clay pipes fragments can come directly from this workshop. From the pipes from $19^{\text {th }}-20^{\text {th }}$ century we meet the producers of pipes from Banská Štiavnica, Kremnica, Miskolc and Male Ozorovce. We have succeeded in identifying several new brands whose producers have not yet been known. Analysis of individual files from different regions of Slovakia gradually shows certain regional differences. In recent years, interest in processing this attractive kind of material culture has increased, resulting in conferences and seminars dedicated to the history, archaeology of pipes, smoking and tobacco.

\section{ÚVOD}

Cielom príspevku je priblížit podrobnosti o archeologických nálezoch fajok na Spiši. Nadväzujeme pritom na články publikované v Studijných zvestiach AUU SAV (Bielich 2016; Čurný et al. 2013; Čurný/Šimč́k/Bielich 2013). Pre účely tohto príspevku sa na zhodnotenie dostala väčšina fajok zo zbierky pobočky Archeologického ústavu SAV v Spišskej Novej Vsi. V stručnosti predstavujeme lokality (obr. 1), z ktorých fajky pochádzajú. Všeobecne možno povedat', že väčšina je zo zberov a nálezové okolnosti nám pri datovaní nepomohli. Pri zarad’ovaní a datovaní fajok vychádzame z ich morfológie a výzdoby v spojení s analogickými nálezmi najmä z územia Slovenska, Mad’arska a Pol'ska. Identifikujeme aj výrobcov podla značiek. Na základe dostupnej literatúry sme ich priradili $\mathrm{k}$ jednotlivým fajkárskym dielňam, ktoré pôsobili v Uhorsku. V úvode analýzy neobídeme ani najstaršiu doloženú fajkársku dielňu na Slovensku, ktorá bola preskúmaná A. Vallaškom (1983) na Spišskom hrade v 70. rokoch 20. stor. Počas výskumu bolo objavených množstvo fajok (okolo 150 ks), kadluby na ich výrobu a fajka s vyrytým letopočtom.

\section{STAV ARCHEOLOGICKÉHO BÁDANIA O HLINENÝCH FAJKÁCH NA SPIŠI}

Problematika archeologických nálezov hlinených fajok a histórie fajkárstva na Spiši doposial' nepatrila medzi bádatel'ské priority. Primát v tejto oblasti má „,nestor“ archeológie stredoveku B. Polla (1971, 115, obr. 100), ktorý ako jeden z prvých autorov venoval spracovaniu nálezov fajok samostatnú stat v publikácii o výsledkoch historicko-archeologického výskumu hradu v Kežmarku. Dôležitým okamihom bol rok 1975, kedy bola objavená fajkárska dielňa na Spišskom hrade (Fiala/Vallašek 1975). Nálezy z tohto výskumu publikoval A. Vallašek (1983). Hlinené fajky zo Spišského hradu a Kežmarku zapracoval do prvej slovenskej monografie o fajkách Š. Holčík $(1984,25)$. Významnou osobnostou archeológie druhej polovice min. stor. na Spiši bol pracovník pobočky Archeologického ústavu SAV v Spišskej Novej Vsi F. Javorský, 


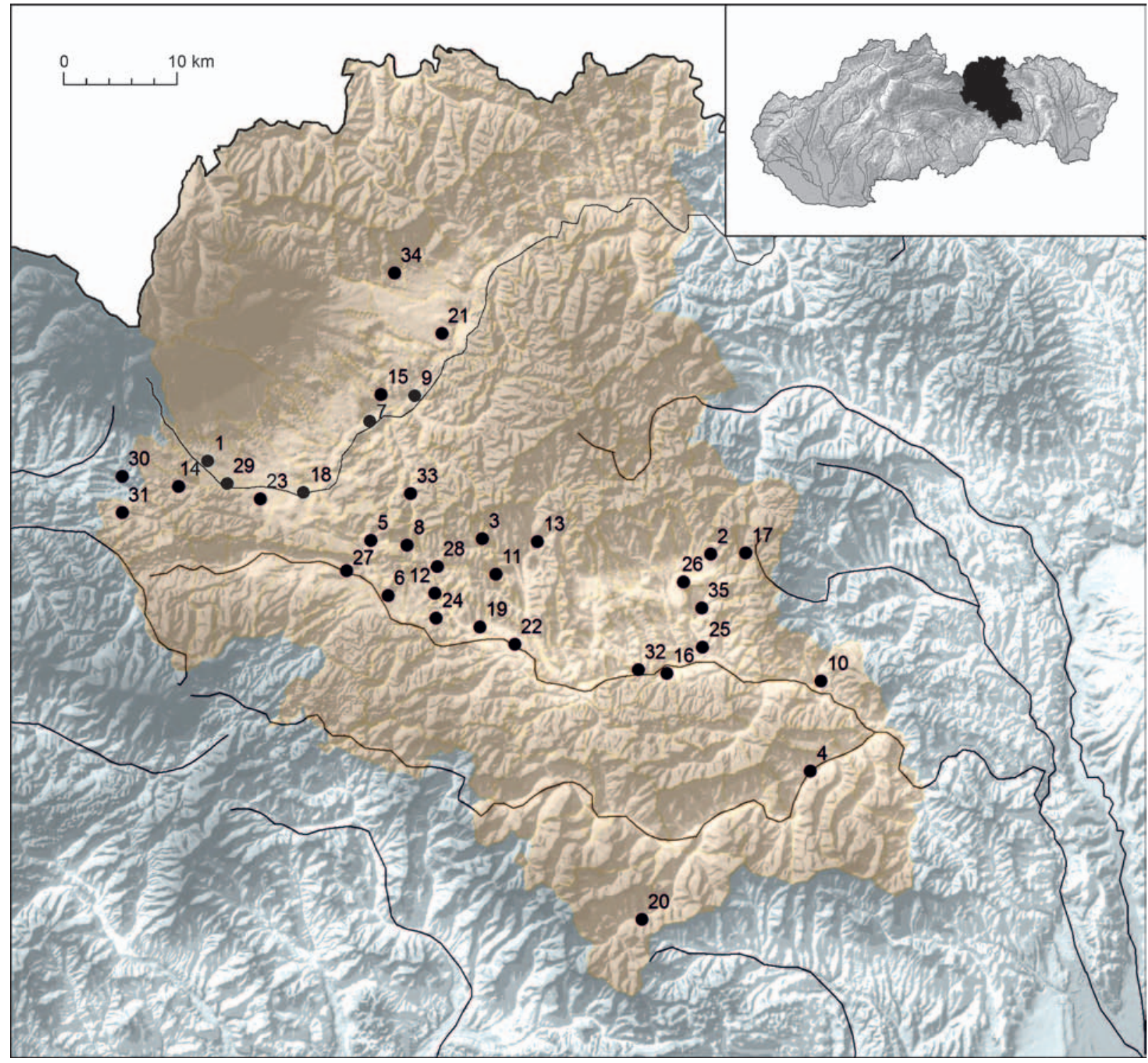

Obr. 1. Lokalizácia nálezov fajok na Spiši (mapa M. Bartík a M. Bielich).

ktorý v rámci svojich terénnych aktivít v rokoch 1967-2000 zozbieral množstvo hlinených fajok. Žial', tieto novoveké nálezy nepublikoval. Na sklonku 20. a začiatkom 21. stor. si na Spiši nálezy fajok z archeologických výskumov a prieskumov všimli P. Roth a M. Soják, z ktorých niektoré aj publikovali (Roth 1991a; 1991b; Roth/Mišenko 2001; Soják 1995; 2000; 2001; 2002; Soják/Suchý 2006). Najnovším nálezom fajok z kežmarského hradu sa venovali M. Čurný a M. Kučerová (2017).

\section{METODIKA A KATALÓG NÁLEZOV}

V príspevku sú predstavené lokality s nálezmi hlinených fajok. Okrem stručného historického kontextu bola pozornosṫ venovaná aj skutočnosti, či sa $\mathrm{v}$ dostupných písomných prameňoch vyskytli aj zmienky o miestnej fajkárskej výrobe alebo iných činnostiach zviazaných s fajčením (napr. o pestovaní tabaku). Väčšina hlinených fajok pochádza z povrchových prieskumov. Fajky z archeologických výskumov evidujeme iba na troch lokalitách (Spišská Nová Ves, Spišský Štvrtok a Vítkovce). V dalšom kroku sme jednotlivé fajky opísali podla aktuálneho databázového zápisu (Čurný/Šimčík/Bielich 2013). V poslednej fáze sme sa snažili fajky chronologicky rozdelit podla tradičného delenia a vyvodit závery zovšeobecňujúce nové informácie o fenoméne fajčenia na Spiši v minulosti. Zaujímavostou štúdia nálezov 
fajok zo Spiša je možnost', či sa osobitné postavenie regiónu Spiša v novoveku mimo Uhorska, počas tzv. pol'ského zálohu, odrazilo aj v štruktúre nálezov fajok. Najnovšie publikácie z juhovýchodného Pol’ska (okolia Krakova) naznačujú, že tamojšia skladba nálezov fajok bola pod vplyvom západných jednodielnych fajok, no objavujú sa aj fajky tureckého typu (Puziuk 2015, 73, obr. 1).

\section{Lokality a katalóg nálezov}

\section{Batizovce, okr. Poprad}

Obec sa prvýkrát spomína v písomných prameňoch z roku 1264. Založil ju na zákupnom práve komes Botyz, syn Marka z Markušoviec, ktorému daroval v roku 1264 Belo IV. les Chetene. Neskôr patrila obec Máriássyovcom. Obyvatelia sa zaoberali polnohospodárstvom, lesnými prácami, pálením uhlia, chytaním pstruhov, hrnčiarstvom a tkaním lanového plátna. Bola tu tehelňa, ktorú zrušili v roku 1965 (Kropilák 1977a, 150). Fragmenty siedmich hlinených dvojdielnych fajok pochádzajú z povrchového zberu M. Sojáka a A. Suchého z roku 2005 v katastri obce, poloha Vyšné Lošy II, Malé pole a Pánske zahumnie (tab. I: 1-7; Soják/Suchý 2006, 188-190).

\section{Bijacovce, okr. Levoča}

Obec je v písomných prameňoch prvýkrát doložená z roku 1258 ako (terra) Bech. Patrila spišskému hradu. Po tatárskom vpáde ju panovník odobral štyrom tamojším zemanom a v roku 1258 dal spišským Nemcom. V 15. stor. Bijacovce pripojili Zápol’skovci znova k hradu. Odvtedy boli majetkom Zápol'skovcov, Thurzovcov a Csákyovcov. V rokoch 1749- 1780 sa tu uvádza solný sklad. Obyvatelia sa živili pol’nohospodárstvom, povozníctvom a službami hradu (Kropilák 1977a, 164). Fragment dvojdielnej hlinenej fajky pochádza z povrchového prieskumu M. Sojáka, poloha Pod kaštielom z roku 2002 (tab. I: 8).

\section{Dlhé Stráže, okr. Levoča}

Obec je spomínaná prvýkrát v písomných prameňoch v roku 1278 ako Bicere. V roku 1317 bola majetkom Levoče, v roku 1360 ju kúpili Iliašovce. Po zmene niekol'kých majitel’ov sa v 16. stor. znova stala vlastníctvom Levoče. V roku 1667 mala šest’ poddaných a šest’ želiarov. Obyvatelia obce sa zaoberali hlavne pol'nohospodárstvom (Kropilák 1977a, 321). Fragment dvojdielnej hlinenej fajky bol objavený pri povrchovom prieskume F. Javorského v roku 1984, poloha Kaplnka pri križovatke (tab. I: 9).

\section{Gelnica, okr. Gelnica}

Prvá písomná zmienka o Gelnici (Gylnychbanya) sa datuje do roku 1246 a ako vyvinuté mesto sa spomína do roku 1276. V 15. stor. význam mesta poklesol, v rokoch 1465-1838 bolo príslušenstvom Spišského hradného panstva. V 18. a 19. stor. sa tu dolovala med’ a spracovávala ortut'. Remeselníci sa podiel’ali na údržbe baní a v 19. stor. boli známi najmä ako klinčiari a ret̉aziari. V roku 1892 bola postavená elektráreň (Kropilák 1977a, 386). Fragment dvojdielnej hlinenej fajky bol získaný povrchovým zberom F. Javorského z neznámej polohy v katastri mesta Gelnica (tab. I: 10).

\section{Hôrka-Ondrej, okr. Poprad}

Chotár svätého Ondreja bol vymedzený už v roku 1273, ale s prvou písomnou zmienkou o dedine sa stretávame až v roku 1315. Z katastra obce pochádzajú z povrchových zberov F. Javorského a M. Sojáka tri fragmenty dvojdielnych hlinených fajok z polôh Kratiny (tab. I: 11, 12) a Komárovce (tab. I: 13).

\section{Hrabušice, okr. Spišská Nová Ves}

Prvá písomná zmienka o Hrabušiciach pochádza z roku 1279, kedy sa nazývala Compositi.

Patrila do Spoločenstva spišských Sasov, v roku 1465 sa stala majetkom panstva Spišského hradu. V rokoch 1582-1638 užívala jarmočné právo. Bol tu mlyn, píla a výroba piva. Obyvatelia sa zaoberali polnohospodárstvom aj povozníctvom. Csákyovci tu postavili hámre a vysokú pec (Kropilák 1977a, 450). Fragment dvojdielnej hlinenej fajky bol získaný povrchovým zberom F. Javorského z neznámej polohy v katastri obce Hrabušice (tab. I: 14).

\section{Huncovce, okr. Kežmarok}

Obec je prvýkrát doložená v písomných prameňoch z roku 1257 ako Supch. Od konca 18. stor. tu bola známa rabínska škola. Začiatkom 19. stor. tu prevažovalo židovské obyvatel’stvo, ktoré sa zaoberalo polnohospodárstvom, plátenníctvom, remeslom a obchodom (Kropilák 1977a, 473, 474). Fragment dvojdielnej hlinenej fajky bol získaný povrchovým zberom F. Javorského v roku 1986, poloha Feldscheid II v katastri obce (tab. I: 15).

\section{Jánovce, okr. Poprad}

Obec je v písomných prameňoch prvýkrát spomínaná v roku 1261 ako Belcella. V roku 1427 mala 20 port. Obyvatelia sa zaoberali pol'nohospodárstvom, výrobou dreveného náradia a kolovrátkov. V 19. stor. tu mali majetok Dessewffyovci (Kropilák 1977a, 510). Fragmenty ôsmich dvojdielnych hlinených fajok z katastra obce pochádzajú z povrchových zberov F. Javorského v roku 1983, poloha Pod hradiskom a M. Sojáka v roku 2000, poloha Pri machalovskej križovatke (tab. I: 16-24). 


\section{Kežmarok, okr. Kežmarok}

Mesto Kežmarok vzniklo v 13. stor. spojením troch osád, a to slovenskej rybárskej osady, osady královských pohraničných strážcov a nemeckej osady. Prvá písomná zmienka o Kežmarku sa nachádza v darovacej listine krála Bela IV. z roku 1251. Mesto získalo mestské výsady v roku 1269 a v roku 1380 sa stalo slobodným královským mestom. V 15.-19. stor. tu pracovalo vyše 40 cechov. Fragmenty troch dvojdielnych hlinených fajok pochádzajú z povrchového zberu F. Javorského v roku 1974 a 1975 v blízkosti rímsko-katolíckeho kostola (tab. I: 25-27).

\section{Kluknava, okr. Gelnica}

Prvá písomná zmienka o Kluknave sa datuje do roku 1304, kedy sa nazývala Plichnow. Patrila Richnavskému hradnému panstvu, v roku 1693 ju dostali Csákyovci a stala sa sídlom jednej vetvy rodiny. V obci boli bane na železo, ortut a med' (Kropilák 1977a, 34, 35). Fragment dvojdielnej hlinenej fajky, získaný povrchovým zberom F. Javorského v roku 1982, pochádza z neznámej polohy v katastri obce (tab. I: 28).

\section{Kurimany, okr. Levoča}

Obec je doložená prvýkrát v písomných prameňoch v roku 1258 ako Sanctus Quirinus. Patrila do Spoločenstva spišských Sasov a v roku 1465 pripadla Spišskému hradnému panstvu (Kropilák 1977a, 120). Fragment dvojdielnej hlinenej fajky bol získaný v roku 1982 povrchovým zberom F. Javorského, poloha Pod Rambergom (tab. I: 29).

\section{Letanovce, okr. Spišská Nová Ves}

Obec Letanovce je v písomných prameňoch doložená v roku 1250 ako Lethon. V roku 1259 ju Belo IV. daroval spišskému prepoštovi aj s dávkami. V rokoch 1305-1307 postavili na Skale útočišta kláštor, známy vynikajúcim skriptóriom. V roku 1436 kláštor vyhorel a v 1543 ho Levočania zborili. Letanovce tak pripadli Spišskej Kapitule (Kropilák 1977b, 145). Z povrchového prieskumu M. Sojáka, poloha Severný svah Čertovej, pochádza mosadzné kónické viečko fajky (tab. I: 30).

\section{Levoča, okr. Levoča}

Levoča vznikla z troch pôvodných slovanských osád a osady nemeckých kolonistov, ktorí sa tu usídlili v roku 1241 po tatárskom vpáde na pozvanie Belu IV. Najstarším písomným dokladom, v ktorom sa prvýkrát vyskytuje pomenovanie Levoče ako "Leucha“, je listina krála Bela IV. z roku 1249. V roku 1271 sa Levoča stala hlavným mestom Spoločenstva spišských Sasov. V roku 1317 sa už spomína výslovne ako královské mesto. Vývoj mesta prerušil v 16. stor. rozsiahly požiar a v 17. stor. protihabsburské povstania. Napriek tomu Levoča v tomto období zostala centrom Spiša. Fragmenty fajok pochádzajú z viacerých polôh v meste. Staršie nálezy dvojdielnych hlinených fajok pochádzajú zo zberov F. Javorského, a to v polohe dvor OSC (tab. II: 4) a výkop pre plynovod (tab. II: 2, 3). Novšie nálezy sú zo zberov M. Sojáka v priestore mestského opevnenia - hradieb (tab. II: 1), SV bašty (tab. II: 7) a parkánového múra (tab. II: 6).

\section{Lučivná, okr. Poprad}

Obec je prvýkrát v písomných prameňoch doložená v roku 1321 ako Lutzina. V 16. stor. patrila Kežmarku, v roku 1753 ju kúpila rodina Várady-Rakmáry, majetok tu mali aj Máriássyovci. V 18. stor. tu bola poštová stanica, tridsiatkový úrad a tažil sa vápenec (Kropilák 1977b, 200). Fragmenty troch dvojdielnych hlinených fajok pochádzajú z povrchového zberu F. Javorského v roku 1984, poloha Nad skalami (tab. II: 8-10).

\section{Malý Slavkov, okr. Kežmarok}

Obec je v písomných prameňoch prvýkrát spomínaná v roku 1251 ako Zolok. Malý Slavkov patril medzi poddanské obce Kežmarku (Kropilák 1977b, 227). Fragment dvojdielnej hlinenej fajky pochádza z povrchového zberu M. Sojáka v roku 2010, poloha Pri ošipárni (tab. II: 11).

\section{Olcnava, okr. Spišská Nová Ves}

Obec sa spomína v písomných prameňoch prvýkrát v roku 1312 ako Altznow, quaevilla alibi Detriciappellatur. Jej zakladatel'om bol Detre. Patrila Richnavskému panstvu a v roku 1693 sa dostala do majetku Csákyovcov (Kropilák 1977b, 343). Fragment dvojdielnej hlinenej fajky pochádza z povrchového zberu M. Sojáka z roku 2010, poloha Starý cintorín (tab. II: 12)

\section{Polanovce, okr. Levoča}

Pol’anovce sa prvýkrát v písomných prameňoch spomínajú v roku 1270, ked’ ich dal Štefan V. Urovmu synovi Fiókovi výmenou za vežu na Spišskom hrade. Od 18. stor. patrili rodine Jancsovcov, Almássyovcov a iným (Kropilák 1977b, 415). Fragment dvojdielnej hlinenej fajky pochádza z povrchového zberu M. Sojáka v roku 2014, poloha Sihoł’ (tab. II: 13).

\section{Poprad, okr. Poprad}

V roku 1256 sa prvý raz objavuje písomná zmienka o Poprade ako o samostatnej obci osídlenej nemeckými pristahovalcami. V polovici 14. stor. sa Poprad spolu s d’alšími spišskými obcami stal súčastou provincie 24 spišských miest, s ktorou sa v roku 1412 dostal do tzv. pol'ského zálohu. Po skončení zálohu v roku 1772 patril Poprad do provincie 
16 spišských miest, kde zostal až do roku 1876. Z katastra Popradu evidujeme z povrchových zberov M. Sojáka nálezy šiestich dvojdielnych hlinených fajok z viacerých polôh, a to Zadné rovne (tab. II: 14, 15), Pri chodníku (tab. II: 16), Pod lesom (tab. II: 17), areál Whirlpool (tab. II: 18) a Vyšné záhradky (tab. II: 19).

\section{Smižany, okr. Spišská Nová Ves}

Prvá písomná zmienka o obci Smižany sa datuje do roku 1246, kedy sa nazývala Micha. Stará obec patrila královským psovodom zo Spišskéhu hradu. Čast’ pozemkov odkúpili v roku 1254 od pôvodných obyvatelov Nemci. Obec v roku 1293 prijali do spoločenstva spišských Sasov. V 2. polovici 15. stor. sa stala poddanským mestečkom Spišského hradu. Do roku 1815 malo solný sklad, v 18. stor. sa tu t’ažil žltý a hnedý mramor. Csákyovcom patrila výnosná tažba dreva a v 19. stor. tri vysoké pece. Posledná pracovala do roku 1886 (Kropilák 1978, 58). Fragment dvojdielnej hlinenej fajky pochádza z povrchového zberu M. Sojáka v roku 2012 z polohy Smižianska roveň (tab. II: 20).

\section{Smolník, okr. Gelnica}

Prvá písomná zmienka o Smolníku sa datuje do roku 1327, kedy sa nazýval Semelnech. Starú banícku obec osídlili v 13. stor. Nemci z Gelnice. V polovici 15. stor. pripadlo mesto panstvu Spišského hradu, ktoré prenajímalo miestne medené a strieborné bane a hámre. Baníctvo sa začalo rozvíjat najmä v 18. stor. Od začiatku 18. stor. tu pôsobila mincovňa, ktorá zanikla v roku 1816. V meste sa vyrábala modrá a zelená skalica až do roku 1918. Koncom 19. stor. bola zriadená vel'ká tabaková továreň. Pri požiari v roku 1905 obec z dvoch tretín vyhorela. Po roku 1918 pracovali obyvatelia v miestnej tabakovej továrni, v továrni na plech, v baniach, lesoch, na pílach (Kropilák 1978, 61). Fragment dvojdielnej hlinenej fajky pochádza z povrchového zberu F. Javorského v roku 1988, v ryhe pri katolíckom kostole (tab. III: 1).

\section{Spišská Belá, okr. Kežmarok}

Obec je v písomných prameňoch prvýkrát doložená v roku 1263 ako Bela. V 17. stor. bolo mestečko známe týždennými a výročnými trhmi (v roku 1607 získalo jarmočné právo). V 18. stor. bolo strediskom kožiarskych remesiel, kožušníkov, obuvníkov a čižmárov. Tunajšie l’anové plátno sa vyvážalo aj do Turecka. V roku 1778 vznikol liehovar (belianska borovička) a konzerváreň. V 18. stor. tu pracovala vysoká pec a hámre. Začiatkom 19. stor. začala remeselná výroba upadat'. Vznikla tu vel'ká píla, škrobáreň, v roku 1898 tabaková továreň (Kropilák 1978, 70). Dva fragmenty dvojdielnych hlinených fajok pochádzajú z povrchového zberu M. Sojáka z polohy Medvedisko z roku 2003 (tab. III: 3, 4).

\section{Spišská Nová Ves, okr. Spišská Nová Ves}

Prvá písomná zmienka o Spišskej Novej Vsi je z roku 1268, kedy sa spomína ako „Villa Nova“. V roku 1632 Ferdinand II. udelil Spišskej Novej Vsi právo pečatit svoje písomnosti červeným voskom, čo bolo vel'kým vyznamenaním pre mesto. V období rokov 1672-1684 malé družiny povstaleckých Thőkőlyho vojsk dvanást'krát vydrancovali mesto. V rokoch 1709 až 1712 zúril po krutých bojoch povstania Františka Rákoczyho v meste mor, ktorému padlo za obet’ viac ako 2000 ludí. 5. novembra 1772 bolo mesto Spišská Nová Ves pri vel'kej slávnosti vrátené uhorskému královi z pol’ského zálohu. Z katastra mesta pochádza 34 fragmentov dvojdielnych hlinených fajok. Najviac nálezov pochádza z archeologického výskumu kostola Nanebovzatia Panny Márie z roku 2003 (tab. IV: 2, 9-13, 15, 16; V: 1-3, 7-12, 14, 16, 17; Soják 2004, 344, 345). Ďalšie nálezy pochádzajú z povrchových zberov z polôh Kapustnice I (tab. IV: 1; V: 4-6), Letná ulica (tab. V: 13), Smižianska roveň (tab IV: 14), Otex (tab. IV: 5), sídlisko Východ (tab. IV: 4), Pri Ferčekovciach (tab. IV: 3), Námestie (tab. IV: 6-8) a Múzeum Spiša (tab. V: 15).

\section{Spišská Teplica, okr. Poprad}

Obec je v písomných prameňoch prvýkrát doložená z roku 1280 ako Toplica. Bola zemepanským mestečkom cisterciánskeho opátstva v Spišskom Štiavniku. V roku 1530 ju panstvo založilo Levoči, v roku 1697 ju vykúpili jezuiti. Od roku 1776 patrila Spišskému biskupstvu. Od stredoveku sa tu konali týždenné trhy a od roku 1755 dva výročné jarmoky. V 18. stor. sa obyvatel'stvo živilo polnohospodárstvom, drevárstvom, pálením liehu (Kropilák 1978, 75). Z katastra obce pochádza sedem fragmentov dvojdielnych hlinených fajok, ktoré boli objavené počas povrchových prieskumov M. Sojáka a V. Habaja v rokoch 2001-2002, poloha Pod kameňom (tab. III: 5-9), Kríž pri bývalej papierni (tab. III: 11) a Ždiarec (tab. III: 10).

\section{Spišské Tomášovce, okr. Spišská Nová Ves}

Prvá písomná zmienka o Spišských Tomášovciach sa datuje do roku 1229, kedy sa nazývala VillaThome. V roku 1415 získali čast’ obce kartuziáni zo Skaly útočišta, neskôr im patrila celá obec. V roku 1550 ju Ferdinand I. daroval Spišskej kapitule, čoskoro sa ale dostala do vlastníctva šlachty (Kropilák 1978, 76). Tri fragmenty dvojdielnych hlinených fajok pochádzajú z povrchového zberu F. Javorského, poloha Pod hradiskom, v roku 1979 (tab. III: 12-14).

\section{Spišské Vlachy, okr. Spišská Nová Ves}

Prvá písomná zmienka o Spišských Vlachoch sa datuje do roku 1243, kedy sa nazývala Olazi. Obec patrila v roku 1317 do Spoločenstva spišských Sasov a vyvíjala sa ako mestečko. Do 18. stor. sa v chotári dobývala medená ruda a pracovala medená huta. Koncom 18. stor. tu bol významnejší farbiarsky cech. V roku 1876 založili Spišskovlašskú-krompašskú sporitelňu, tehelňu, neskôr parnú pílu. Obec silne poškodil požiar v roku 1924 (Kropilák1978, 79). Pät fragmentov dvojdielnych hlinených fajok pochádza z povrchových prieskumov M. Sojáka, poloha JZ od kóty 446 (tab. III: 15) a Plantal v roku 2008 (tab. III: 16-19). 


\section{Spišský Štiavnik, okr. Poprad}

Obec vznikla na mieste starého benediktínskeho kláštora z 10.- 11. stor. Prvýkrát je doložená v písomných prameňoch z roku 1246 ako Scinik. Obec i opátstvo v roku 1260 zhoreli. Kláštor v roku 1531 vypálili Levočania. Štiavnické panstvo dostal v roku 1539 Hieronym Laský, nakrátko Thurzovci, po nich Ján Rueber. V roku 1579-1674 boli pánmi Tőkőlyovci, do roku 1773 jezuiti a od roku 1776 patrilo Spišskému biskupstvu (Kropilák 1978, 80). Fragment dvojdielnej hlinenej fajky pochádza z povrchového zberu M. Sojáka, poloha Nad rybníkom (tab. VI: 2).

\section{Spišský Štvrtok, okr. Levoča}

Obec je doložená z roku 1263 ako VillaSanctiLadislai. Obec dosídlovali Nemci, v roku 1336 panovník potvrdil jej príslušnost’ grófovi Spoločenstva Spišských Sasov a Spišský štvrtok sa vyvíjal ako mestečko (Kropilák 1978, 81). Dva fragmenty dvojdielnych hlinených fajok pochádzajú z povrchových zberov M. Sojáka, poloha Ovsisko III a Balistarií-Strelce. V roku 1999 prebiehal archeologický výskum v polohe Smykanec, ktorý viedol F. Javorský. Počas výskumu bolo objavených sedem fragmentov dvojdielnych hlinených fajok (tab. VI: 3-9).

\section{Svit, okr. Poprad}

V roku 1934 vybudovala firma Bat’a západne od Popradu továreň na syntetické vlákna. Postupne tu vyrástlo sídlisko Svit. V roku 1946 sa stalo samostatnou obcou. Dva fragmenty dvojdielnych hlinených fajok pochádzajú z povrchového prieskumu M. Sojáka v roku 2002 z polohy Pod skalkou (tab. VI: 10, 11).

\section{9. Štrba, okr. Poprad}

Obec je v písomných prameňoch prvý raz doložená v roku 1280 ako Chorba. Patrila Szentiványiovcom, Szmrecsániovcom, Baanovcom a trom vetvám Bohumírovho potomstva. V roku 1580 je doložená tunajšia píla (Kropilák 1978, 140). Dva fragmenty dvojdielnych hlinených fajok pochádzajú z povrchového prieskumu M. Sojáka v roku 2013, poloha Šoldov (tab. VI: 12, 13).

\section{0. Šuňava, okr. Poprad}

Obec Nižná Šuňava je doložená prvýkrát v písomných prameňoch v roku 1321 ako Schonaw. Patrila cisterciátskemu opátstvu v Spišskom Štiavniku. V 14. stor. ju vlastnili Szentiványiovci, ktorí ju v roku 1346 poručili kartuziánom zo Skaly útočišta. Potom patrila Červenému kláštoru, jezuitom a napokon študijnej základine (Kropilák 1978, 320). V roku 1974 sa Nižná a Vyšná Šuňava zlúčili do obce Šuňava. Fragment dvojdielnej hlinenej fajky pochádza z povrchového prieskumu M. Sojáka v roku 2001, poloha za Michalkom (tab. VI: 14).

\section{Vítkovce, okr. Spišská Nová Ves}

Prvá písomná zmienka o obci Vítkovce sa datuje do roku 1279, kedy sa nazývala Vytk. Neskôr obec patrila Spišskej kapitule (Kropilák 1978, 272). V roku 1979 prebiehal archeologický výskum v polohe Tureň, ktorý viedol F. Javorský (1980, 119). Počas výskumu hradiska z neskorej doby bronzovej bol v objekte 10 objavený fragment dvojdielnej hlinenej fajky (tab. VI: 16).

\section{Vlková, okr. Kežmarok}

Obec je v písomných prameňoch prvýkrát doložená v roku 1278 ako Farcasfolwa. V 18. stor. bola železiarskou obcou (Kropilák 1978, 276). Fragment dvojdielnej hlinenej fajky pochádza z povrchového zberu M. Sojáka v roku 2009, poloha Pod Okrúhlou (tab. VI: 17).

\section{Výborná, okr. Kežmarok}

Obec Výborná je doložená prvý raz v písomných prameňoch v roku 1289 ako Birburn (Kropilák 1978, 292). Fragment dvojdielnej hlinenej fajky pochádza z povrchového zberu M. Sojáka, poloha Dlhé Výhony I. (tab. VI: 15).

\section{4. Žehra, okr. Spišská Nová Ves}

Prvá písomná zmienka o obci Žehra sa datuje do roku 1245, kedy sa nazývala Sygura.

Comes Ján zo Žehry dostal povolenie postavit’ tu kostol. Patrila Zsigrayovcom, no po ich vymretí Spišskému hradnému panstvu. V 18. stor. sa tu nachádzal mlyn, píla a vel'ké rybníky (Kropilák 1978, 376-378). Pät fragmentov dvojdielnych hlinených fajok pochádza z povrchových zberov F. Javorského v roku 1988, v bezprostrednom okolí Spišského hradu (obr. 2; tab. VI: 18-21).

Do katastra obce patrí aj Spišský hrad, ktorý sa prvý raz spomína v roku 1120. Jeho výstavba pokračovala po

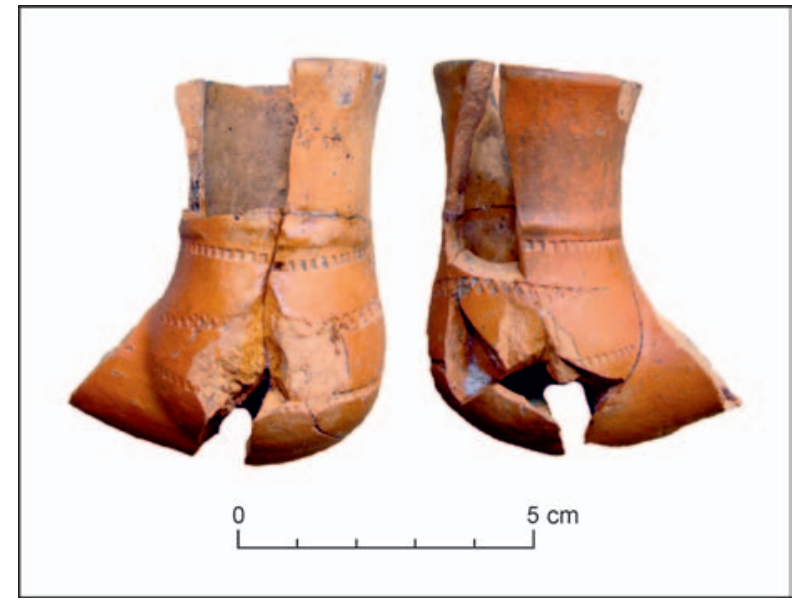

Obr. 2. Keramická fajka zo Žehry. Foto M. Bielich. 

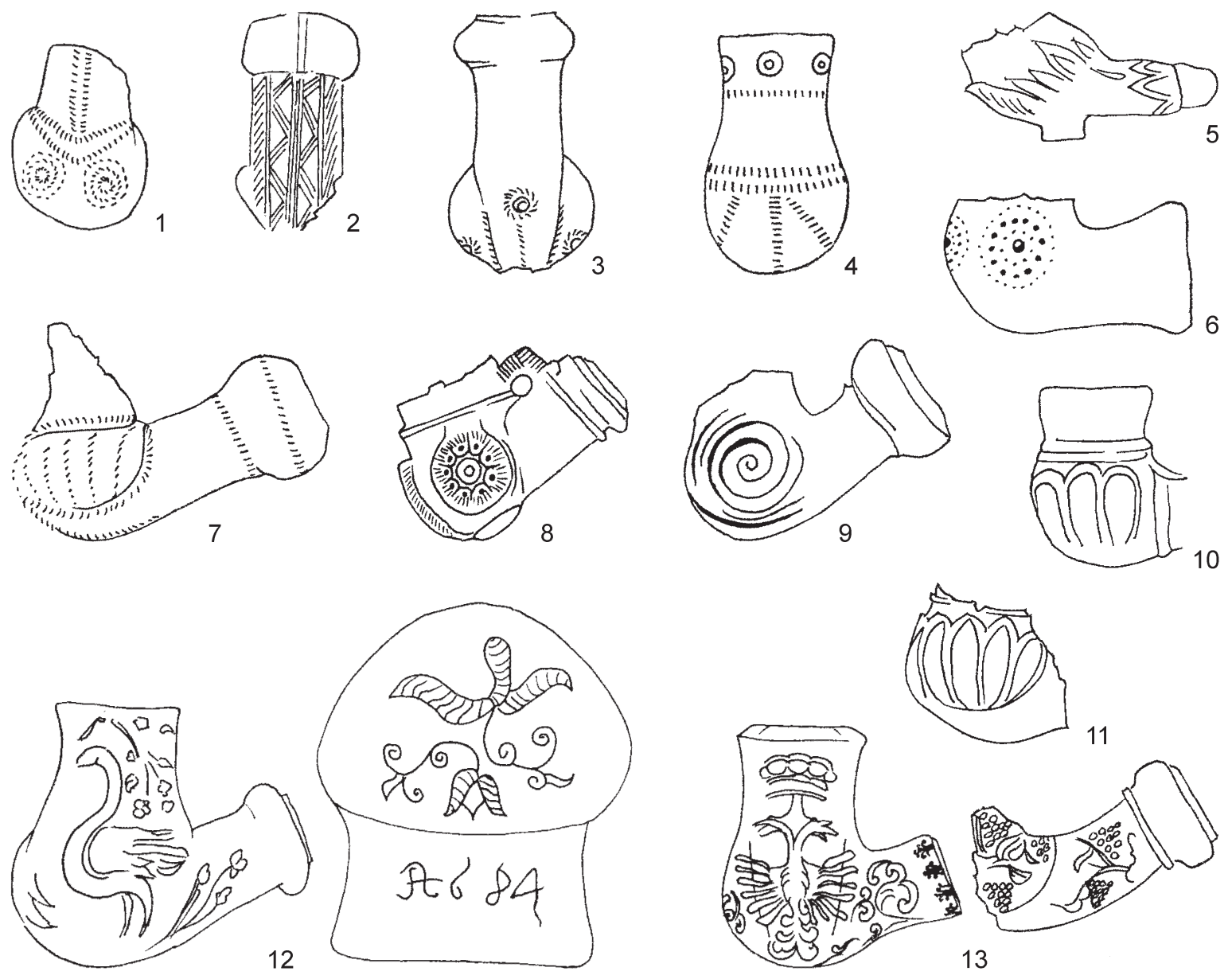

Obr. 3. Spišský hrad. Výber fajok (Vallašek 1983).

roku 1249, ked' dal Belo IV. spišskému prepoštovi na hrade miesto pre postavenie paláca a veže. Pôvodne bol hrad královský, neskôr bol sídlom spišských županov. Hrad bol obývaný do roku 1710, posádka ho opustila po požiari v roku 1780 (Kropilák 1978, 376-378). Pät fragmentov dvojdielnych hlinených fajok pochádza z povrchového zberu M. Sojáka v okolí Spišského hradu (tab. III: 20-24).

\section{VYHODNOTENIE}

Pri vyhodnocovaní archeologických nálezov fajok a ich presnejšom časovom zatriedovaní nám chýbajú širšie nálezové kontexty. Takmer výhradne ide o nálezy z povrchových prieskumov, výnimočne z archeologických výskumov (Spišský Štvrtok, Vítkovce, Spišská Nová Ves). V skúmanom súbore bolo vyhodnotených 127 hlinených (keramických) fajok. Pri ich triedení a datovaní sa v najväčšej miere stále môžeme opierat’ o poznatky ich morfológii úprave povrchu, výzdobe a v neposlednom rade aj o značkovaní. Doterajšia suma poznatkov, ktorá vyplýva z množstva najmä v zahraničí publikovaných nálezov, umožňuje predbežne stanovit dobu vzniku predmetných výrobkov aspoň podla storočí.

\section{Dielňa na Spišskom hrade}

Najstaršia fajkárska dielňa, ktorá je zároveň jediná archeologicky skúmaná na území Slovenska, je doložená na Spišskom hrade. V roku 1975 sa uskutočnil výskum románskeho predhradia Spišského hradu, pri ktorom bola v priestore bránovej veže zachytená fajkárska dielňa (Fiala/Vallašek 1975; 


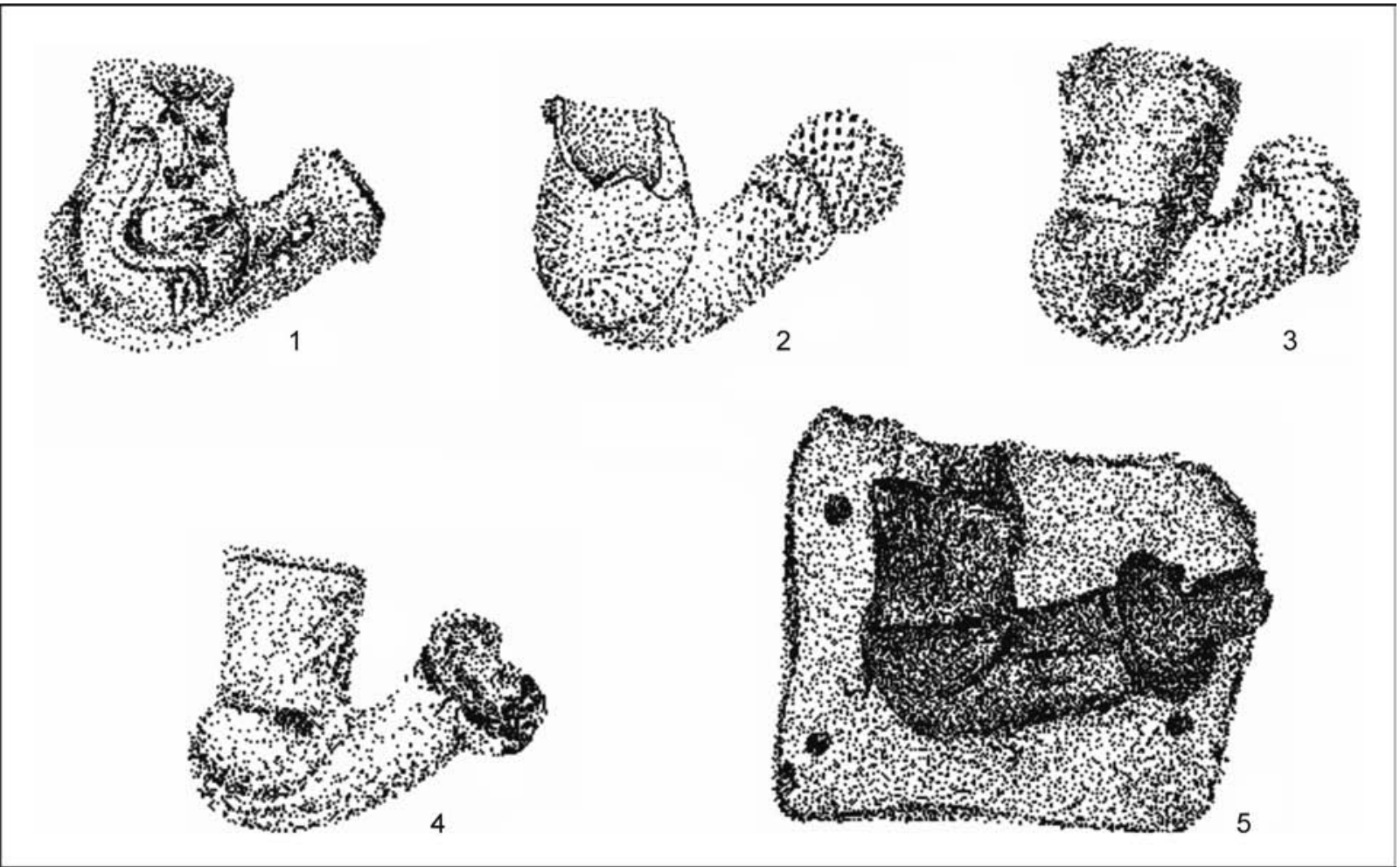

Obr. 4. Spišský hrad. Výber fajok (Vallašek 1983).

Vallašek 1979), tú potom samostatne spracoval A. Vallašek (1983). Miestnost' s tehlovou pecou na vypalovanie fajok sa nachádzala $\mathrm{v}$ budove, ktorá vznikla na prelome 16.-17. stor. (obr. 6). $\mathrm{V}$ miestnosti boli objavené hotové fajky, nepodarky a forma na výrobu fajok (obr. 3; 5). Spolu bolo objavených až 150 fajok (Vallašek 1983, 236). Fajky boli vyrobené z jemne plavenej hliny. Farba fajok bola rôzna. Boli objavené čierne, červené a glazované fajky (hnedá transparentná a transparentná bezfarebná glazúra). Pred vypálením boli zdobené rytou výzdobou. Objavujú sa zvieracie (obr. 3: 9, 11), rastlinné (obr. 3: 12) a rastlinno-geometrické motívy (obr. 3: 6; Vallašek 1983, 238). Je zjavné, že nie všetky fajky, ktoré boli publikované, sú produktmi hradnej dielne. Zaujímavý je najmä fragment jednodielnej fajky (obr. 3: 15), ktorý je určite importom v súbore

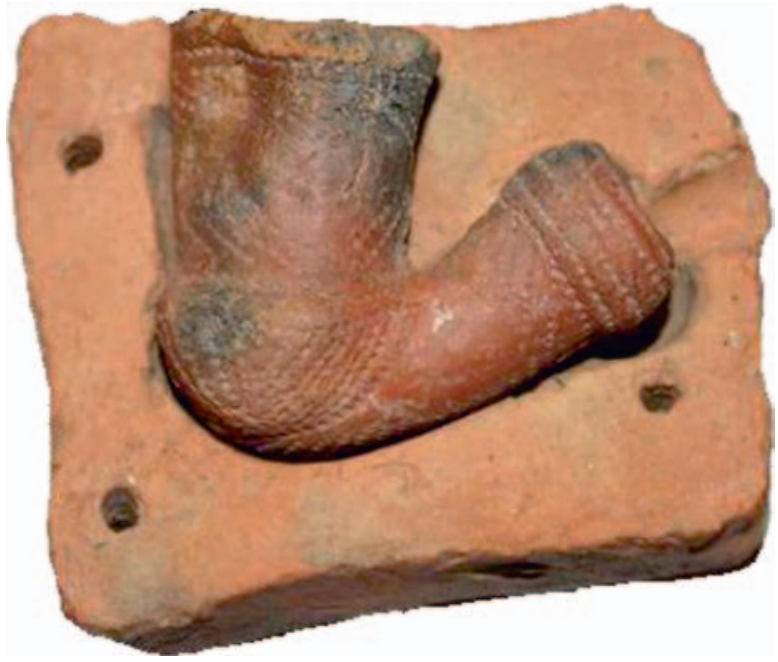

Obr. 5. Spišský hrad. Forma na výrobu fajok. Foto M. Čurný. fajok z hradu (Vallašek 1983, 237, obr. 7: 15). Fajka s vyrytým letopočtom 1684 (obr. 3: 10) datuje existenciu dielne až na koniec 17. stor. Kadlub na dvojdielne fajky s valcovitou hlavičkou a zosilneným ukončením kŕčka (obr. 5) datuje produkcie fajok do 17.-18. stor. Doteraz ojedinelým dokladom výroby fajok v prostredí hradov je nález z výskumu Koháriho paláca na hrade Muráň, kde sa medzi viacerými fajkami objavil aj jeden hlinený nepodarok (Malček/Mitáš 2016, 55). Na rozdiel od Spišského hradu tu nemožno hovorit’ o dielni na výrobu fajok, skôr iba o individuálnej výrobe pre vlastnú potrebu, azda vynútenú okolnostami. S podobnými nálezmi, ktoré súvisia s výrobou, sa stretávame aj v Mad’arsku pri výskume hradu v Szegede (Kondorosy 2008, 356). Výroba fajok ako "pekelného náčinia“ v druhej polovici 17. stor. sa pravdepodobne ukrývala aj v priestore hradov, ale hlavne v prostredí anonymných 


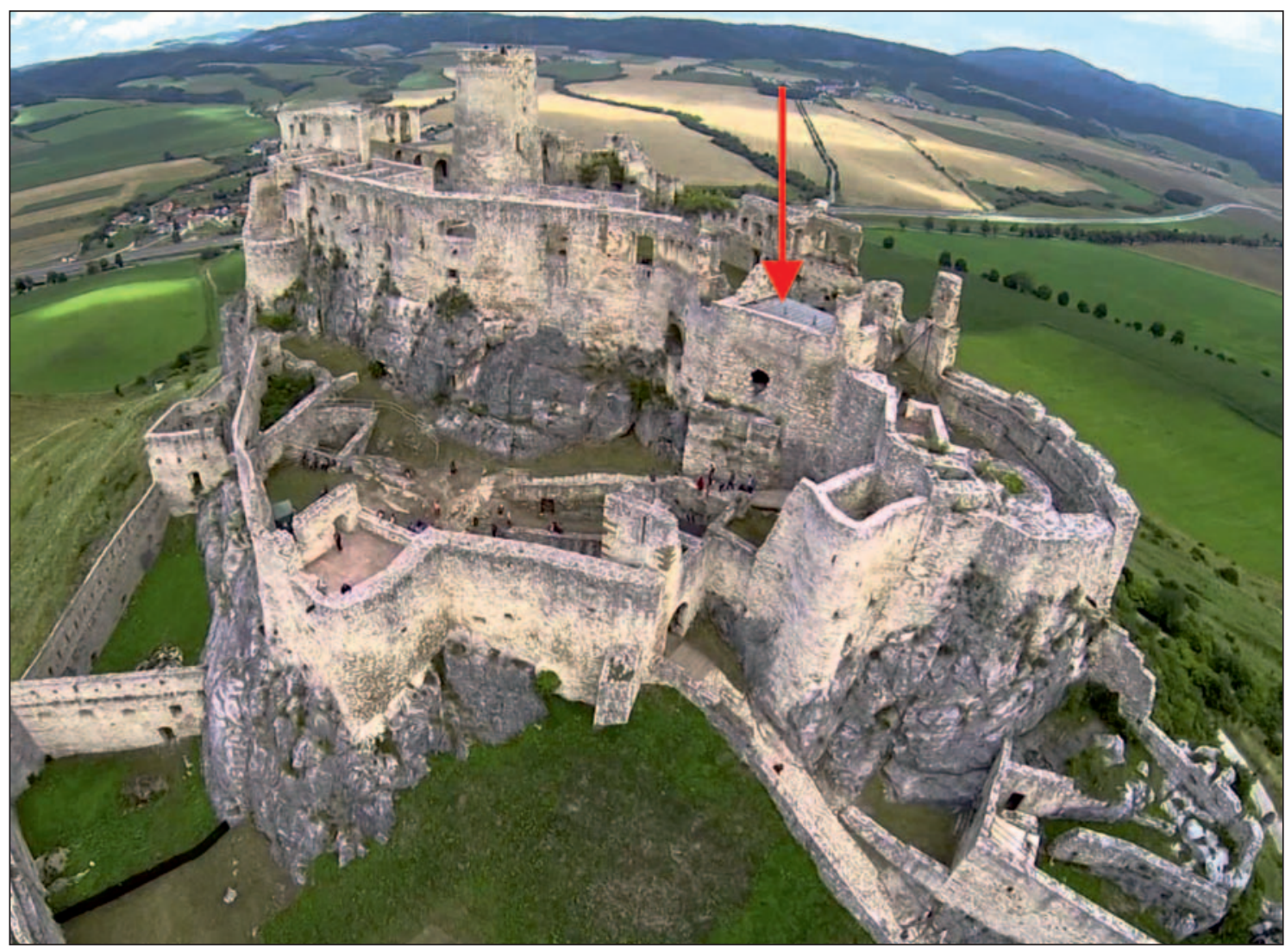

Obr. 6. Spišský hrad - lokalizácia fajkárskej dielne (https://www.youtube.com/watch?v=GUF3d9AuD2U [6. 5. 2019]).

hrnčiarskych dielní. Hrady v tomto období strácali svoju obrannú funkciu. V ich priestoroch sa pohybovali žoldnieri zo západu Európy a aj vojaci, ktorí boli v kontakte s Osmanmi, hlavnými konzumentmi tabaku. Tí priniesli fajčenie do Karpatskej kotliny.

Fajky z konca 17.-18. stor.

Najväčšia čast̉ fajok zo Spiša pochádza zo 17.-18. stor. Ide o obdobie, kedy sa fajkárska produkcia u nás postupne legalizovala. Fajky boli na začiatku považované za pekelný nástroj a boli zakazované. $\mathrm{S}$ fajčením priamo súvisí pestovanie a predaj tabaku, ktorého monopol v Habsburskej monarchii patril panovníkovi. Fajky až do konca 18. stor. vyrábali najskôr malí domáci výrobcovia. Najstaršia dielňa, produkujúca od 17. stor. do roku 1780, bola archeologicky preskúmaná na Spišskom hrade (Vallašek 1979, 236-240; 1983, 236, 238). V období okolo prelomu 18. a 19. stor. sa domáca výroba fajok sústredila hlavne do miest (Banská Štiavnica, Bratislava, Nitra, Zvolen, Pukanec) alebo ich blízkosti (okolie Lučenca atd’). Do konca 18. stor. sú nálezy zo Slovenska bez značiek, čo st’ažuje ich datovanie a identifikáciu výrobcov. Hlinené dvojdielne fajky z tohto obdobia boli vyrábané v drevených alebo kovových formách a zdobené technikami, ktoré používali keramikári.

Hlavičky sú vo väčšine prípadov obyčajného valcovitého tvaru a na kŕčok nasadajú v ostrom uhle. Pre kŕčok týchto fajok je typické prstencovité zosilnenie otvoru pre pipasár, manžety (tab. IV: 7, 8; VI: 1). Výzdoba sa $\mathrm{v}$ tomto období vyskytuje $\mathrm{v}$ dvojakom prevedení. Bud' ide o plastickú výzdobu umiestňovanú v prevažnej miere po stranách hlavičky, ktorá vznikla v matrici, alebo je to výzdoba rytá, resp. odtlačovaná za mokra do vylisovaného polotovaru fajky, a to najčastejšie pomocou radielka alebo iného typária. Plastickú výzdobu predstavujú najčastejšie drobné pupákovité výčnelky usporiadané do geometrického tvaru, kosoštvorca (tab. VI: 3). Rytá a radielkovaná výzdoba bývajú umiestnené zväčša na manžete kŕčka (tab. V: 2) a na samotný kŕčok (tab. III: 1, 11). Motív výzdoby radielkom je mnohokrát jednoduchý štvorčekovaný (tab. VI: 5, 6) alebo ide o drobný vruborez, ktorý pozostáva z pozdížnych a oblúkovitých línií 
(tab. V: 2). Samostatnú skupinu predstavuje nález zlomku hlavičky fajky v tvare „hlavy Turka“ (tab. V: 1). Tento typ fajky je charakteristický pre obdobie 18. až začiatok 19. stor. a objavuje sa v Prahe (Námestie republiky) aj vo Vroclavi (Vyšohlíd 2009, 981, obr. 19). Vo výnimočných prípadoch sa na fajkách vyskytuje aj transparentná žltá glazúra (tab. III: 8; IV: 3; V: 9). Opísaný typ dvojdielnych fajok sa začal vyskytovat pravdepodobne ešte $\mathrm{v}$ 17. stor. a pravdepodobne reflektoval na potreby odberatelov týchto výrobkov, tureckých a žoldnierskych vojsk v Uhorsku, preto možno hovorit aj o tureckom type fajok (Harman/Šteffek 2008, tab. IV; XV). V skúmanom súbore sa nachádza vel'ká skupina fajok tzv. tureckého typu, ktoré sa vyskytujú najmä v priebehu 18. stor. (tab. I: 24; IV: 5; V: 10; VI: 12, 19). Vyznačujú sa geometricko-rastlinou výzdobou na hlavičke fajky. Vd’aka vypáleniu v oxidačnom prostredí je farba týchto fajok svetlohnedá, červená a oranžová.

Fajky z 19.-20. stor.

V súbore sa podarilo na základe značiek identifikovat’ výrobky z ôsmich fajkárskych dielní pôsobiacich počas 19.-20. stor. na území habsburskej monarchie. Je vel'mi zaujímavé, že v skúmanom súbore je menší počet fajok z oblasti Banskej Štiavnice. Vel'ký počet zostáva neurčený, a to najmä z dôvodu ich slabej zachovalosti, kedy sa stretávame iba s malými fragmentmi, na ktorých sa nezachovali výraznejšie morfologické či iné identifikačné prvky. Pri dvojdielnych fajkách bola najcitlivejšou častou práve hlavička, ktorá podstupovala najväčšie tepelné výkyvy pri fajčení. Ďalšiu skupinu nálezov predstavujú inak poškodené fajky, ktoré navyše prešli určitou fázou archeologickej transformácie, teda k dispozícii sú často iba amorfné torzá fajok.

Aj v nálezovom fonde fajok z 19. stor., pochádzajúcom z výskumných aktivít pobočky Archeologického ústavu SAV v Spišskej Novej Vsi, nezaberajú najväčšie percento fajky banskoštiavnickej proveniencie a iba v ojedinelých prípadoch ide o domácich a rakúsko-uhorských, resp. neidentifikovaných výrobcov.

Samostatnú skupinu nálezov tvoria dva kovové vrchnáčiky. Počas spracovania nálezov sme skúmali jedno ihlanovité viečko z Letanoviec (tab. I: 30) a polkruhovité viečko zo Spišskej Novej Vsi, ktoré boli vyrobené z farebného kovu (medzi, resp. mosadze; tab. IV: 11). Výroba vrchnáčikov a kovaní tvorí samostatnú a uzavretú čast’ výroby hlinených fajok, ktorá sa mohla a obyčajne aj realizovala formou subdodávok pre fajkársku výrobu. Hoci z hladiska celkového hodnotenia ich úspešnosti bolo rozhodujúce vyhotovenie vlastnej hlinenej fajky, predsa výroba kovových súčasti tvorila vel'kú čast' sumárnej výroby. Svedči o tom napr. i pomerne rozsiahle technické zariadenie úseku pri Zacharovej dielni v Banskej Štiavnici (Sprušanský 1968, 229).

\section{Značky výrobcov fajok zo Spiša}

\section{ROTHMAN W. KREMNITZ}

V skúmanom súbore sú dve fajky s týmto kolkom z Popradu (tab. II: 19) a Spišskej Novej Vsi (tab. V: 8). Pochádzajú pravdepodobne od doposial neznámeho výrobcu z Kremnice. Żiadne informácie o tomto fajkárovi sa nepodarilo zatial' doložit (Šteffek 2007, 15-17). Na základe technického prevedenia je možné túto dielňu datovat' na koniec 19. stor. Skúmaná fajka je čiernej farby s osemhrannou hlavičkou a mušlovito vyformovaným kŕčkom fajky. Na lavej strane sa nachádza kolok so zobrazením erbu Uhorska, na pravej strane je autorský kolok ROTHMAN W. KREMNITZ.

\section{E. STIASNY SCHEMNITZ}

Na dvore farskej záhrady v Spišskej Novej Vsi bola objavená d’alšia fajka z produkcie mesta Kremnica (tab. V: 14). V polovici 19. stor. pracovali v Kremnici tri fajkárske dielne, z ktorých sa najznámejšou stala neskoršia manufaktúra E. Štiasneho (Štiaszny, Štiassny; Harman/Šteffek 2008, 42). Vo výrobe fajok pokračoval jeho syn Štefan s matkou, kým na ňu, nakol'ko boli židovského pôvodu, v súvislosti s arizáciou majetkov nestratili právo. To sa im nepodarilo uplatnit ani po skončení druhej svetovej vojny. Fajky z dielne E. Štiasného spočiatku zachovávali tvar podobný štiavnickým fajkám, mladšie formy už boli tvarovo pestrejšie. Najviac sa tu vyrábali čierne neglazované dvojdielne fajky. Tvarovo sa nevel'mi odlišuje od štiavnických fajok, najmä Hőnigových a Zacharových. Má šest̉hrannú hlavičku s dnom mušlovitého 
tvaru a krátky krčok zakončený ostro vyformovanou manžetou. Na pravej strane trúbel'ky je značka výrobcu E. STIAASNY KREMNITZ, na lavej strane má dalšiu ochrannú značku v podobe banskoštiavnického mestského znaku. Pri Štiasného fajkách bolo celkom bežné, že pri ich označovaní používal znak Banskej Štiavnice, nakol'ko sa tu vyučil za fajkára a neskôr sa osamostatnil. Táto fajka je datovaná do druhej polovice 19. stor. (Solčániová 2016, 30-41).

\section{K. AZAR}

V polohe Brehy, kataster obce Lučivná, bola objavená čierna fajka s kolkom K. AZAR, čo znamená Kis Azar, teda mad’arská verzia názvu obce Malé Ozorovce, okr. Trebišov. V prvej polovici 19. stor. ich tu vyrábal výrobca Vamossy, ktorý sa po čase presunul do Blatného Potoka (Sárospatak), kde pokračoval s výrobou pod dovtedajším značením (mad'. KIS AZAR). Fajky ozdoboval malým motýlom a boli striebornej alebo popolavošedej farby (Čaplovič 1997, 167). Fajka je na hlavičke bohato geometricky zdobená, pod kŕčkom fajky sa nachádza mušlovite vyformovaná postava (tab. II: 9). Mad’arský bádatel' Z. Nagy túto značku mylne zarad’uje do skupiny mad’arských fajok produkovaných v meste Körmendv Zadunajsku (Nagy 2000, 47). Mohlo by íst’ o napodobnitela výrobcu, ktorý pôsobil v Körmende a používal označenie KAZAR (Nagy 2012, 289).

\section{HŐNIG: WTE SCHEMNITZ}

Na dvore farskej záhrady v Spišskej Novej Vsi bola objavená fajka z dielne A. a M. Hőnigovcov z Banskej Štiavnice (tab. V: 6). Z fajky je zachovaný kŕčok s mušlovito vyformovanou podstavou. Na lavej strane fajky sa nachádza kolok HŐNIG: WTE SCHEMNITZ, na pravej strane erb Banskej Štiavnice. Dielňa vyrábala fajky s týmto kolkom v prvej štvrtine 19. stor. (Lovásová 2014, 32).

\section{HÖNIG: WWE SCHEMNITZ}

V polohe Smykanec, v katastri obce Spišský Štvrtok, sa našla fajka banskoštiavnickej produkcie (tab. VI: 9). Po smrti A. Hőniga chvílu vyrábala fajky dielňa jeho manželky (vdova), predtým ako vo výrobe pokračoval jeho syn Michal (Nagy 2000).

Doposial identifikované značky tejto dielne: HŐNIG W.: SCHEMNITZ, M. HŐNIG: W SCHEMNITZ, HŐNIGWc SCHEMNITZ, M. HOONIG W WE SCHEMNITZ, HŐNIG WE SCHEMNITZ, HŐNIG We: SCHEMNITZ. Dielňa vyrábala fajky s týmto kolkom v rokoch 1838-1860 (Harman/Šteffek 2008, 116; Lovásová 2014, 32).

\section{L. SCHMIDT SCHEMNITZ}

V polohe Pri bývalej papierni, v katastri obce Spišská Teplica, bola objavená trojdielna fajka z dielne banskoštiavnického výrobcu J. Schmidta (tab. III: 11). Dielňu J. Schmidta prebrala jeho dcéra Ludmila a začala od roku 1860 vyrábat fajky so svojím kolkom. Fajky boli ocenené pamätnou medailou na výstave v Budapešti v roku 1885.

Doposial' identifikované značky tejto dielne: L. SCHMIDT SCHEMNITZ, L SCHMIDT SCHEMNITZ. Dielňa vyrábala fajky s týmto kolkom v rokoch 1860-1890 (Harman/Šteffek 2008, 121; Lovásová 2014, 33).

\section{MIHALIK SELMECZ}

Na dvore farskej záhrady v Spišskej Novej Vsi bola objavená d’alšia fajka z produkcie mesta Banská Štiavnica (tab. IV: 16). Dielňa I. Mihalika sa nachádzala v Banskej Štiavnici na Dolnej Resli. O jej existencií píše v roku 1867 Z. Nagy (2000). Neskôr Mihalik výrobu fajok zanechal a stal sa kníhtlačiarom. Doposial' identifikované značky tejto dielne: S. MIHALIK SCHEMNITZ, MIHALIK SELMETZ. Dielňa vyrábala fajky s týmto kolkom v rokoch 1860-1867 (Harman/Šteffek 2008, 118; Lovásová 2014, 39).

\section{SVARTZ ISAK}

V skúmanom súbore sa nachádza fajka zo Spišského hradu s kolkom na lavej strane SVARTZ ISAK (tab. III: 20). Fajka pochádza pravdepodobne od doteraz neznámeho výrobcu zo Spiša a žiadne informácie o fajkárovi sa nepodarilo doložit. Na základe technického prevedenia je možné dielňu datovat na začiatok 19. stor. 


\section{SELMEC STEINGUT}

Pri povrchovom prieskume $\mathrm{v}$ polohe Dlhé hony, $\mathrm{v}$ katastri obce Výborná, sa našiel zlomok fajky so slabo čitatel'ným kolkom SELMEC STEINGUT na lavej strane. Fajka je sivej farby menšieho rozmeru (tab. VI: 15). Dielňa vyrábala fajky s týmto kolkom pravdepodobne v druhej polovici 19. stor. približne do roku 1918.

\section{MONART}

Väčśí fragment dvojdielnej fajky bol objavený v polohe Smykanec, kataster obce Spišský Štvrtok. Na lavej strane kŕčku sa zachoval oválny kolok s nápisom MONART. Typologicky ide o fajky z 19. stor. (tab. VI: 6). Žial', kolok, ktorý sa na fajke nachádza, sa nepodarilo bližšie určit. Fajka má kŕčok s mušlovito vyformovanou podstavou. Na povrchu sa nachádzajú zvyšky zelenkavej transparentnej glazúry s perletovým leskom. Farba hliny na lome je červená. Proveniencia výrobcu je neznáma.

\section{OV.... MISKOLC}

Počas povrchového prieskumu v polohe Dolné rovne, $\mathrm{v}$ katastri mesta Poprad, bola objavená menšia sivá fajka so silne poškodeným pravostranným kolkom. Z vrchného radu sme identifikovali druhé a tretie písmeno OV a z druhého radu slovo MISKOLC (tab. II: 15). Ide pravdepodobne o výrobcu fajok z východného Mad’arska z 19. stor. Bohužial', v písomných a archeologických prameňoch sa nám nepodarilo nájst' informácie o tejto fajkárskej dielni.

\section{Fajky typu CAFE}

Biele fajky typu Cafe alebo tiež tzv. gypsovky súvisia s módnym trendom záveru 19. a začiatku 20. stor., ktoré sa viažu na kaviarne a kaviarenský život. Boli vyrábané zo špeciálnej sadrovej zmesi lisovaním vo formách a vypalované $\mathrm{v}$ bežných hrnčiarskych peciach. Najčastejšie sa vyskytujú vysoké valcovité alebo typické hranolovité hlavičky s relatívne krátkou trúbelkkou. Poznáme však aj gypsovky s malými polgulovitými hlavičkami. Výzdoba sa viazala najmä na hlavičky fajok a vznikala odtlačením vo forme. Najčastejšie išlo o rôzne geometrické lineárne vzory doplnené o figurálne a iné motívy (prekrížené žrde, vázy, kvety, korunky a pod.). Relatívne často sa na nich vyskytuje aj výzdoba aplikovaním hustého perlovca. Podla M. Harmana a J. Šteffeka $(2008,43)$ vychádzali tieto fajky z nemeckých a rakúskych (viedenských) vzorov, odkial' ich prevzali napr. v českom Kolíne. Tu sa ich výrobou preslávil M. Mahler (Martínek 2006). Ich výroba na Slovensku v Kremnici nie je vylúčená, nakol'ko sa v depozitári tamojšieho Múzea mincí a medailí nachádza niekol'ko takýchto fajok so signatúrou Körmöcz a HONI IPAR (Harman/Šteffek 2008, 42). Výrobcov tzv. gypsoviek však muselo byt’ omnoho viac. V skúmanom súbore sa vyskytujú tri fajky typu Café. Sú bielej farby s bohatou geometrickou výzdobou na hlavičke (tab. I: 27; II: 6; IV: 13). Na fajke z Levoče (tab. II: 6) je pravostranná značka EL alebo EI. Pochádzajú z povrchového prieskumu z miest Kežmarok, Levoča a Spišská Nová Ves.

\section{ZÁVER}

Cielom príspevku bolo priblížit nálezy fajok zo Spiša. Skúmaný súbor 127 kusov fajok pochádza zo 17. až 20. stor. Analyzované fajky môžeme chronologicky rozdelit’ do dvoch skupín. Staršia skupina fajok pochádza z konca 17.-18. stor. a mladšia skupina z 19.-20. stor. V skúmanom súbore dominujú hlavne fajky z 18. stor. Na Spišskom hrade je archeologickým výskumom doložená najstaršia dielňa na výrobu fajok na Slovensku (Vallašek 1983). Medzi nálezmi zo Spišského hradu sa vyskytuje aj jeden fragment jednodielnej fajky (obr. 3: 5), ktorý je importom zo západu. Individuálna výroba fajok v čase núdze bola pravdepodobne sústredená do hradov, čo dokazuje aj nový nález „fajkárskej dielne“ na Muránskom hrade (Malček/Mitáš 2016).

Fajkám z 19. stor. nedominujú fajky z okruhu banskoštiavnického fajkárstva, ale stretávame sa tu aj s hojným zastúpením fajok z produkcie z Kremnice, Sárospataku, Miškolca a Körmendu. Pri vel’kom počte nálezov fajok pochádzajúcich z 19. stor. nebolo z dôvodu ich slabej zachovalosti možné určit ich autorstvo. Najcitlivejšou častou fajky bola práve hlavička, ktorá podstupovala najväčšie teplotné zmeny pri fajčení. Medzi značkovanými fajkami sme identifikovali výrobky desiatich výrobcov. V súbore sa nachádzajú fajky od niekol'kých výrobcov z Banskej Štiavnice (A. Hőniga, L. Schmidtovej a I. Mihálika) a niekol'ko fajok pochádza aj od napodobovatelov z blízkej Kremnice (E. Štiasneho a W. Rothmana) a z Malých Ozoroviec (K. Azar). Zaujímavým nálezom je fragment trojdielnej fajky z dielne L. Schmidtovej 
(tab. III: 11). Výrobu fajok prebrala po svojom otcovi Jozefovi a v roku 1885 získala v Budapešti ocenenie (Šteffek 2009, 251). Fajka objavená v Spišskej Teplici by mala patrit práve k výrobkom z 80. rokov 19. stor. Z Kremnice pochádza aj jeden zlomok fajky z konca 19. stor., ktorý sa zaraduje k typu CAFE. Produkciu z východného Madarska zastupuje zlomok fajky z Miškolca, bohužial', bez identifikácie výrobcu. Podarilo sa nám doložit pravdepodobne aj miestneho spišského výrobcu I. Svarca. Tento typ sa objavuje na Slovensku prvýkrát a súvisí s miestnou výrobou v 19. stor. na Spiši. Ďalšími bližšie neidentifikovanými výrobkami sú silne poškodené fajky s kolkami MONART a SELMEC STEINGUT. Kým v prvom prípade ide o doposial úplne neznámu značku, druhá je ochrannou značkou kvality niektorej z banskoštiavnických dielní alebo jej napodobovatela.

Samostatnú skupinu fajok, ktoré sa v 19. stor. vyrábali na Spiši, tvoria drevené fajky. Vyrábali sa v Hrabušiciach a predávali sa na trhoch v Košiciach a Kežmarku. Fajky boli vyrábané z borievkového koreňa (Čaplovič 1997, 162).

Prezentovaný príspevok je katalógovým spracovaním zbierky fajok z pobočky AÚ SAV v Spišskej Novej Vsi, ktorá by z hladiska novovekej archeológie mohla prispiet k poznaniu tohto zaujímavého a pre Slovensko hlavne v 19. a 20. stor. významného odvetvia výroby.

\section{LITERATÚRA}

Bielich 2016

Čaplovič 1997

Čurný/Kučerová 2017

Čurný et al. 2013

Čurný/Šimčík/Bielich 2013

Fiala/Vallašek 1975

Harman/Šteffek 2008

Holčík 1984

Javorský 1980

Kondorosy 2008

Kropilák $1977 a$

Kropilák 1977 b

Kropilák 1978

Lovásová 2014

Malček/Mitáš 2016

Martínek 2006

Nagy 2000

Nagy 2012

Polla 1971

Puziuk 2015

Roth 1991a

Roth $1991 b$

Roth/Mišenko 2001
M. Bielich: Nálezy fajok zo Šale a okolia. Študijné zvesti AÚ SAV 59, 2016, 125-149. J. Čaplovič: Etnografia Slovákov v Uhorsku. Bratislava 1997.

M. Curný/M. Kučerová: Súbor fajok z Kežmarského hradu. Príspevok prednesený na konferencii „História výroby fajok a archeologické nálezy fajok na Slovensku“. Tekovské múzeum v Leviciach, 29. 9. 2017. Levice 2017.

M. Čurný/V. Mitáš/P. Šimčík/M. Žáčik: Nálezy keramických fajok z archeologických výskumov a prospekcií na Slovensku. II. Študijné zvesti AÚ SAV 54, 2013, 189-210.

M. Čurný/P. Šimčík/M. Bielich: Nálezy keramických fajok z archeologických výskumov a prospekcií na Slovensku I. Študijné zvesti AÚ SAV 53, 2013, 85-102.

A. Fiala/A. Vallašek: Spišský hrad. Románske predhradie. Nálezová správa a dielče PPU (Archív ŠUPS Bratislava). Bratislava 1975. Nepublikované.

M. Harman/J. Šteffek: Fajka velebená, fajka zatracovaná. Tlmače 2008.

Š. Holčík. Fajky. Bratislava 1984.

F. Javorský: Výskumy a prieskumy výskumnej expedície Spiš Archeologického ústavu SAV. AVANS 1979, 1980, 108-123.

Sz. Kondorosy: A szegedi vár pipái I. A Móra Ferencz múzeum Évkonyve 6, 2008, 331-364.

M. Kropilák (ed.): Vlastivedný slovník obcí 1. Bratislava 1997, 526.

M. Kropilák (ed.): Vlastivedný slovník obcí 2. Bratislava 1997, 517.

M. Kropilák (ed.): Vlastivedný slovník obcí 3. Bratislava 1978, 532.

E. Lovásová: Štiavničky 1796-1959. Hlinené fajky z Banskej Štiavnice. Banská Štiavnica 2014.

R. Malček/V. Mitáš: Keramické fajky z archeologického výskumu na Muránskom hrade. Gemer-Malohont 12. In: Zborník Gemersko-malohontského múzea v Rimavskej Sobote. Rimavská Sobota 2016, 42-59.

J. Martínek: Tajemný svět dýmek. Betliar 2006.

Z. Nagy: Transdanubian Pipe Manufacturers Associated with Selmecbánya. In: E. Haider/A. Orgona/A. Ridovics (ed.): The History of the Hungarian pipemaker's craft. Hungarian history through the pipemaker's art. Keszthely - Debrecen - Budapest 2000, 45-55.

Z. Nagy: Szemfényvesztés. Agyagpipa Hamisító Műhelyek Körmenden a 19. század első felében. Savaria 35, 2012, 279-299.

B. Polla: Kežmarok. Výsledky historicko archeologického výskumu. Bratislava 1971.

J. Puziuk: Nowozytne fajki z badań archeologicznych w Krakowie. Materiały archeologiczne 40, 2015, 51-85.

P. Roth: Prieskumy v okrese Stará L’ubovňa. AVANS 1989, 1991, 86, 87.

P. Roth: Výskum hradu L'ubovňa. AVANS 1989, 1991, 87.

P. Roth/P. Mišenko: Záchranný výskum na námestí v Starej L'ubovni. AVANS 2000, 2001, 166, 167. 
Soják 1995

Soják 2000

Soják 2001

Soják 2002

Soják 2004

Soják/Suchý 2006

Solčániová 2016

Sprušanský 1968

Šteffek 2007

Šteffek 2009

Vallašek 1979

Vallašek 1983

Vyšohlíd 2009
M. Soják: Nálezy z prieskumov a záchranných exploatácií na Spiši. AVANS 1994, 1995, 114-119.

M. Soják: Nálezy z prieskumov a záchranných exploatácií na Spiši. AVANS 1999, 2000, 110-120.

M. Soják: Terénny prieskum na Spiši. AVANS 2000, 2001, 175-185.

M. Soják: Zaviata minulost’ Spišskej Teplice. In: M. Soják (zost.): Dejiny obce Spišská Teplica. Spišská Teplica 2002, 34-64.

M. Soják: Výskum na nádvorí kostola Nanebovzatia Panny Márie v Spišskej Novej Vsi v roku 2003. In: G. Fusek (zost.): Zborník na počest' Dariny Bialekovej. Nitra 2004, 341-346.

M. Soják/A. Suchý: Prieskum chotára Batizoviec. AVANS 2004, 2006, 188-190.

V. Solčaniová: Kremnické fajky z produkcie rodiny Štasný (pôvodne Štiasny). In: J. Dano (ed.): História výroby fajok a archeologické nálezy fajok na Slovensku II. Zborník príspevkov z II. medzinárodnej konferencie konanej 13. 9. 2013 a z III. medzinárodnej konferencie konanej 10.-9. 11. 9. 2015 v Tekovskom múzeu v Leviciach. Levice 2016, 30-41.

S. Sprušanský: Výroba banskoštiavnických hlinených fajok. Zborník SNM 62. Etnografia 9, 1968, 217-237.

J. Šteffek: Typológia kremnických hlinených fajok (Typology of claypipesfrom Kremnica region). Kremnický letopis 2, 2007, 15-17.

J. Šteffek: Pamätná medaila L. Schmidtovej výrobcovi štiavnických zapekačiek. Zborník Slovenského banského múzea 22, 2009, 251.

A. Vallašek: Niekol'ko novších poznatkov z výskumu Spišského hradu. Pamiatky a príroda 1, 1979, 3-7.

A. Vallašek: Dielňa na výrobu hlinených fajok na Spišskom hrade. Eine Werkstättezur Herstellungtönerner Pfeifenauf der Burg Spišský hrad (ZipserBurg). Archaeologia historica 8, 1983, 233-241.

M. Vyšohlíd: keramické dýmky v archeologických nálezech a jejích vypovídací možnosti. Archeologie vo středních Čechách 13, 2009, 965-1000. 


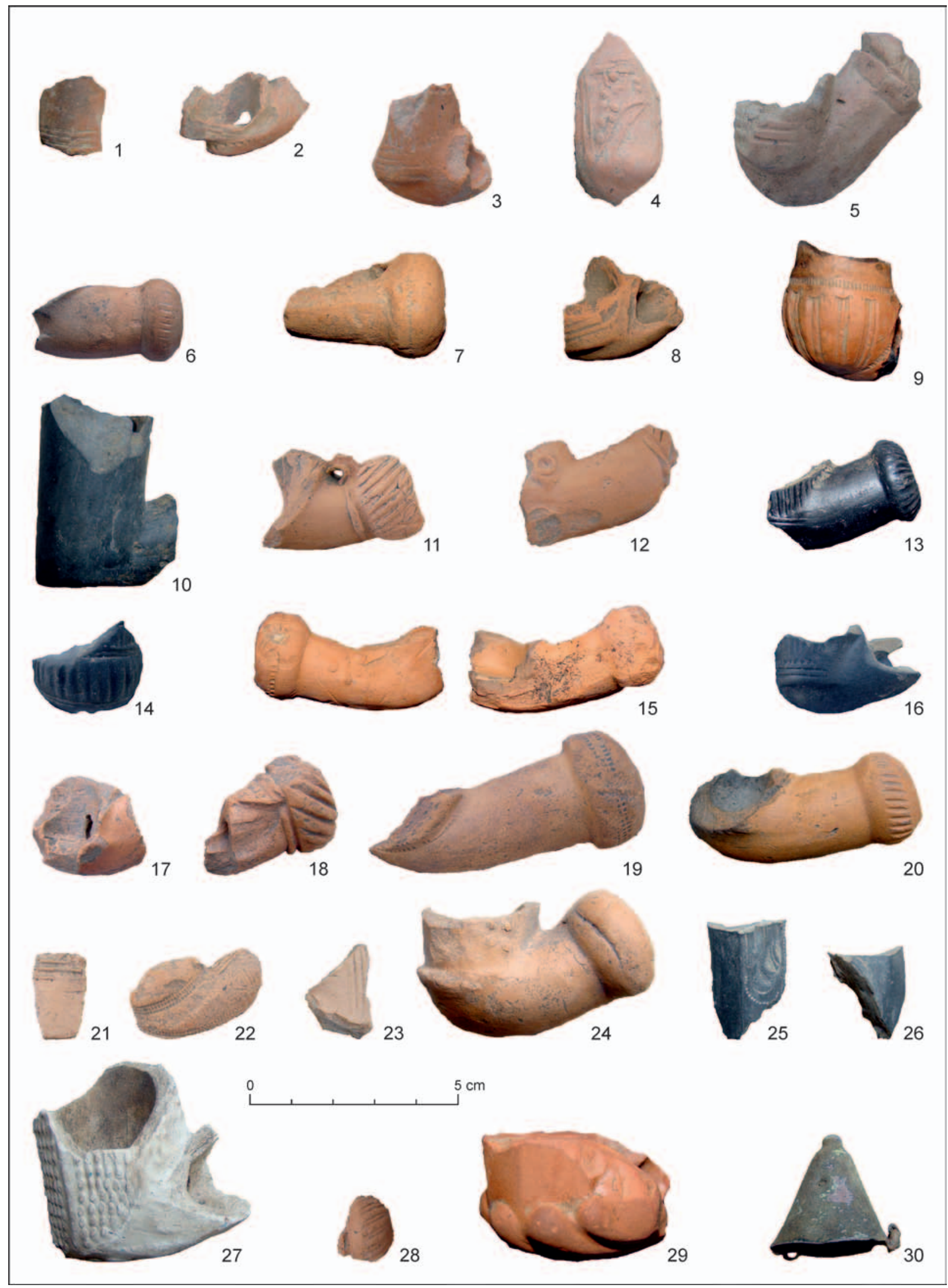

Tab. I. Nálezy keramických fajok zo Spiša. 1-7 - Batizovce; 8 - Bijacovce; 9 - Dlhé Stráže; 10 - Gelnica; 11-13 - Hôrka-Ondrej; 14 - Hrabušice; 15 - Huncovce; 16-24 - Jánovce; 25-27 - Kežmarok; 28 - Kluknava; 29 - Kurimany; 30 - Letanovce. Foto M. Bielich. 


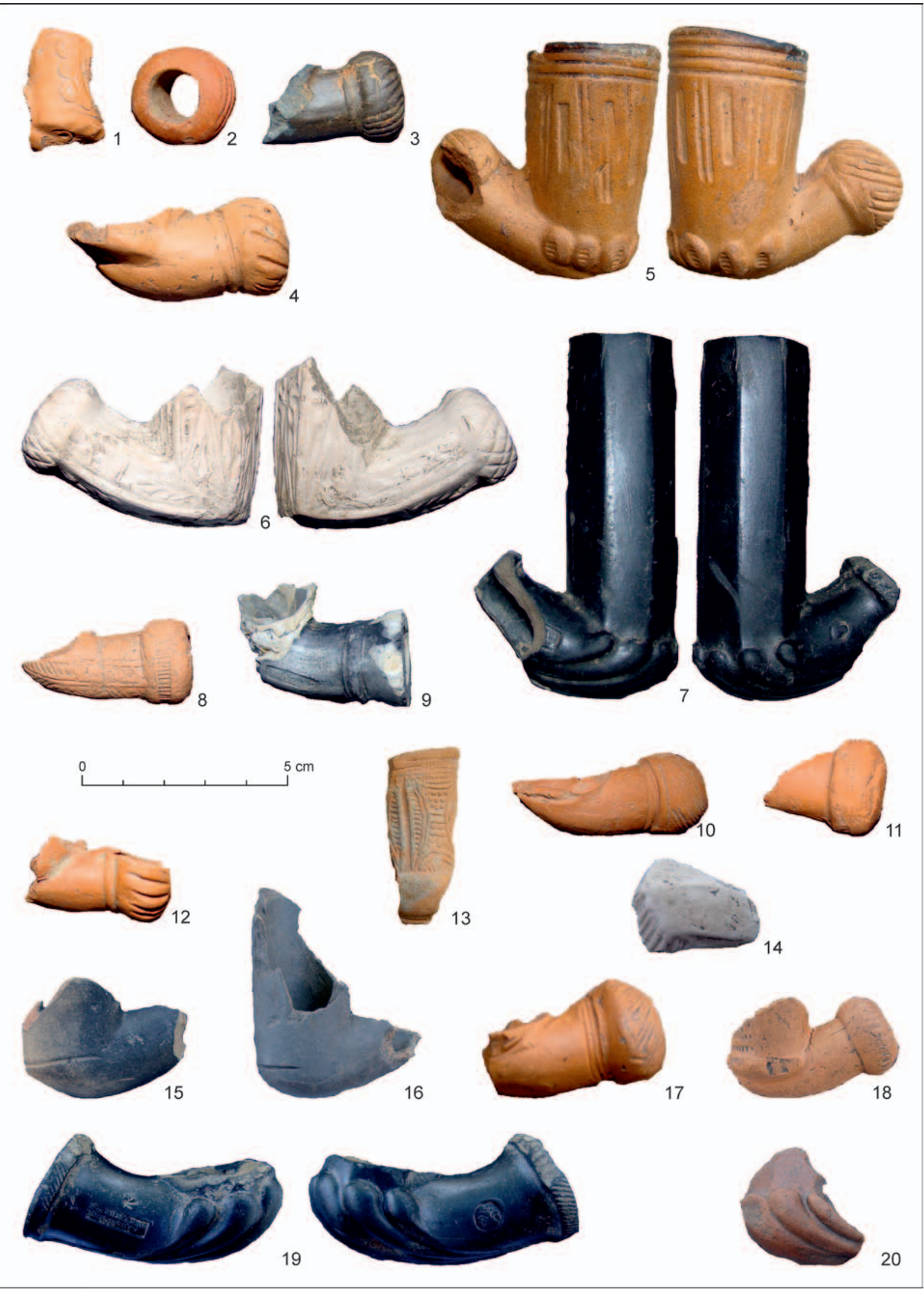

Tab. II. Nálezy keramických fajok zo Spiša. 1-7 - Levoča; 8-10 - Lučivná; 11 - Malý Slavkov; 12 - Olcnava; 13 - Pol’anovce; 14-19 - Poprad; 20 - Smižany. Foto M. Bielich. 


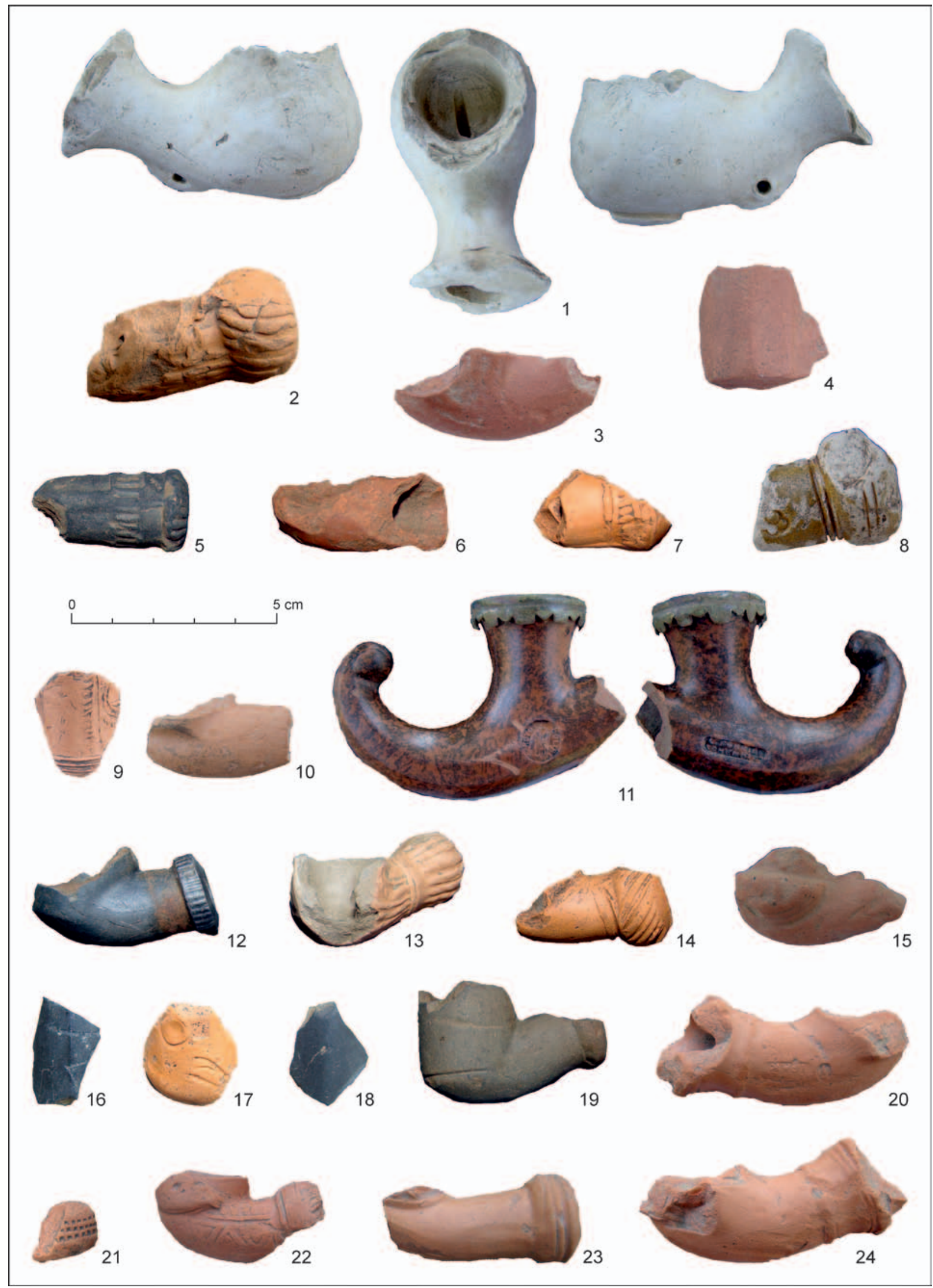

Tab. III. Nálezy keramických fajok zo Spiša. 1 - Smolník; 2 - neznáma lokalita zo Spiša; 3, 4 - Spišská Belá; 5-11 - Spišská Teplica; 12-14 - Spišské Tomášovce; 15-19 - Spišské Vlachy; 20-24 - Spišský hrad. Foto M. Bielich. 


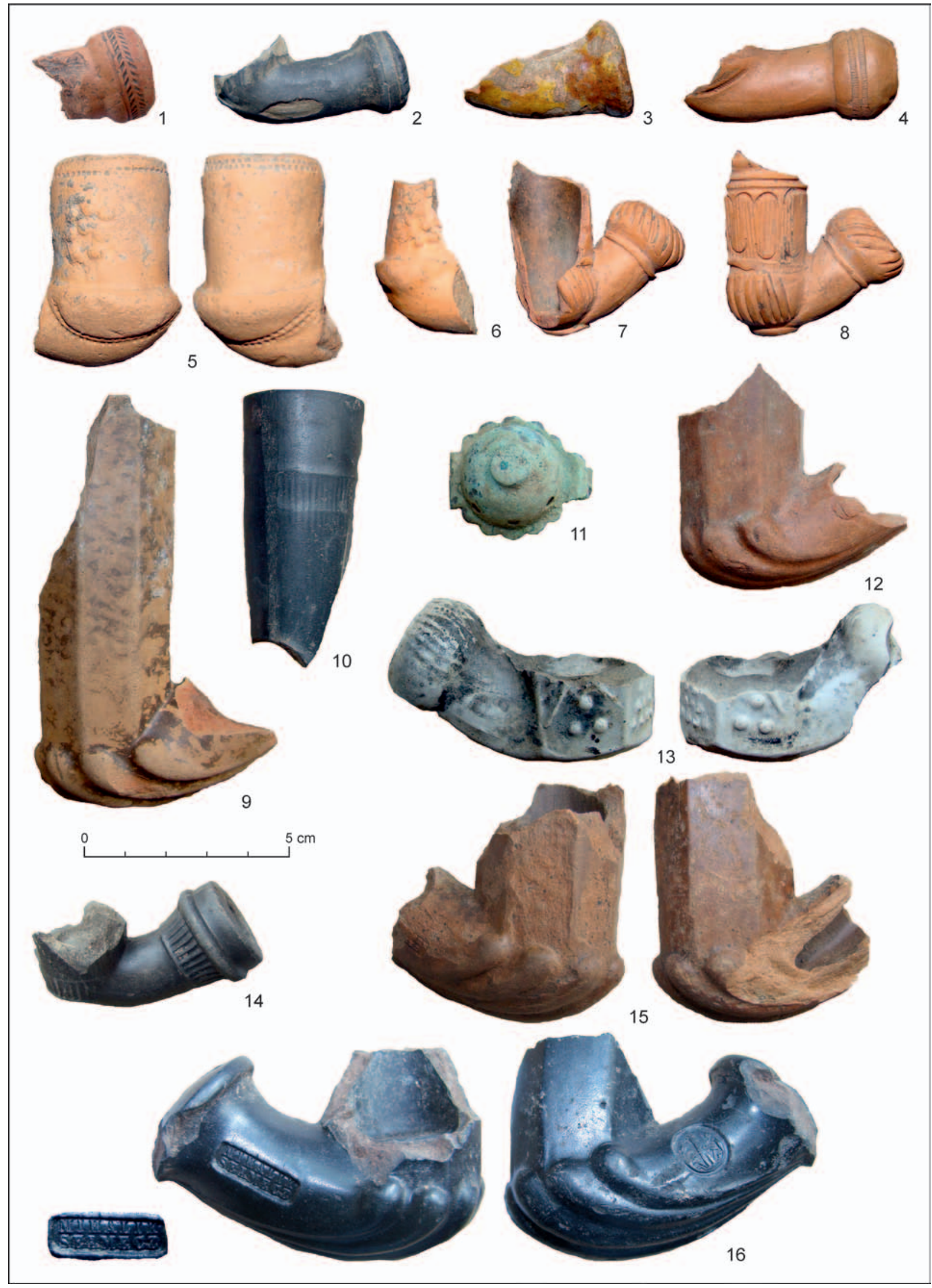

Tab. IV. Nálezy keramických fajok zo Spiša. 1-16 - Spišská Nová Ves. Foto M. Bielich. 

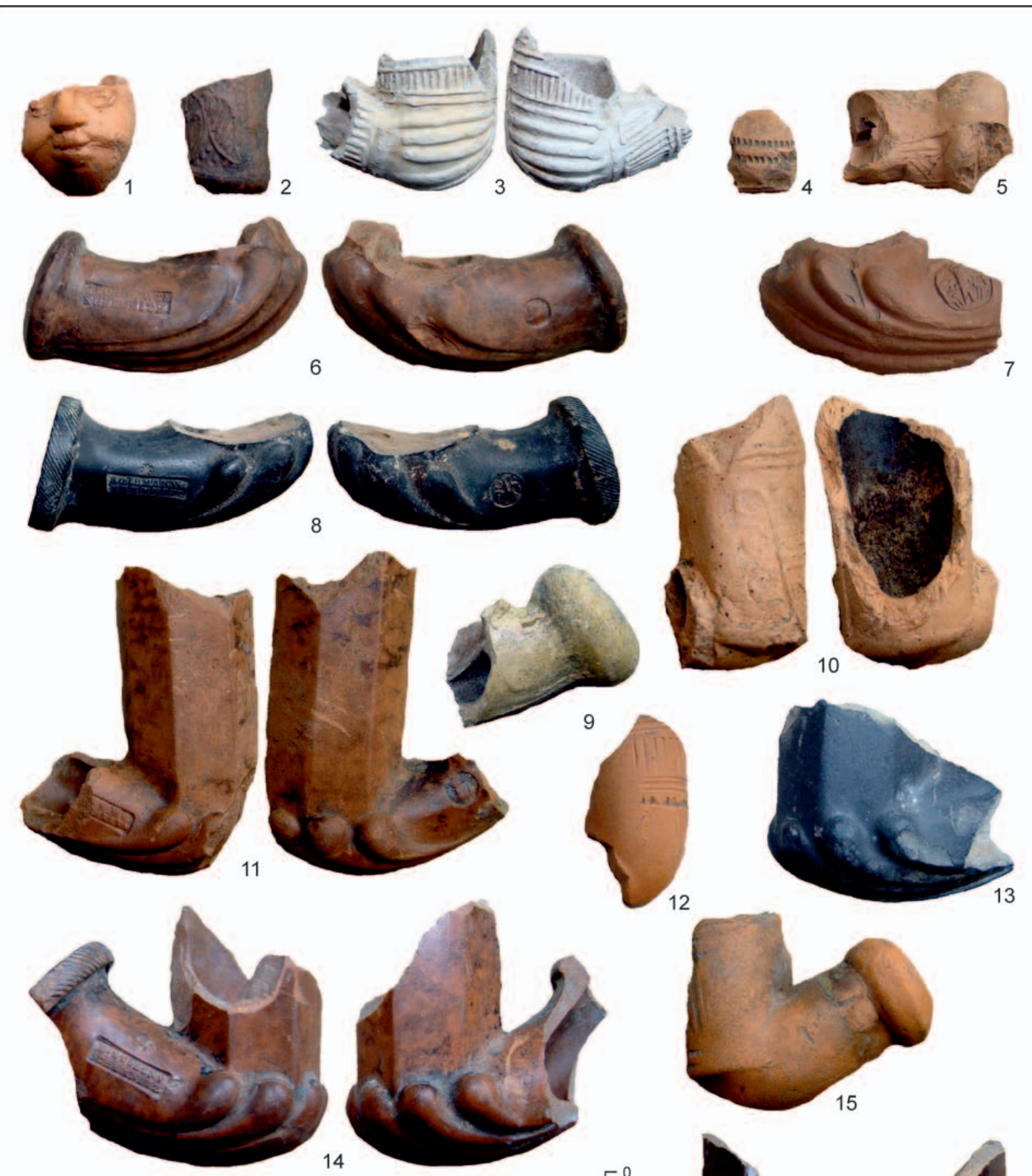

12
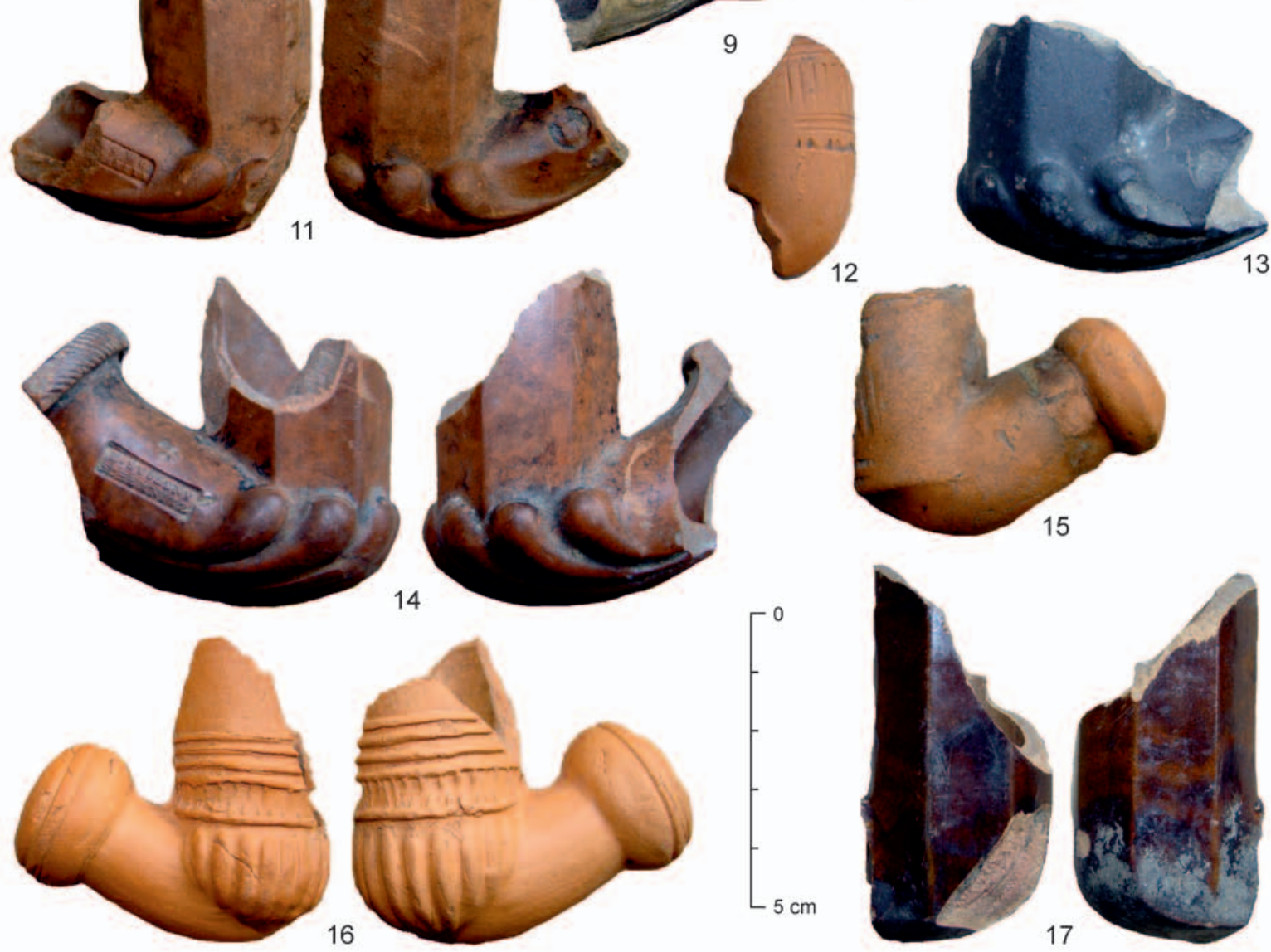

Tab. V. Nálezy keramických fajok zo Spiša. 1-17 - Spišská Nová Ves. Foto M. Bielich. 


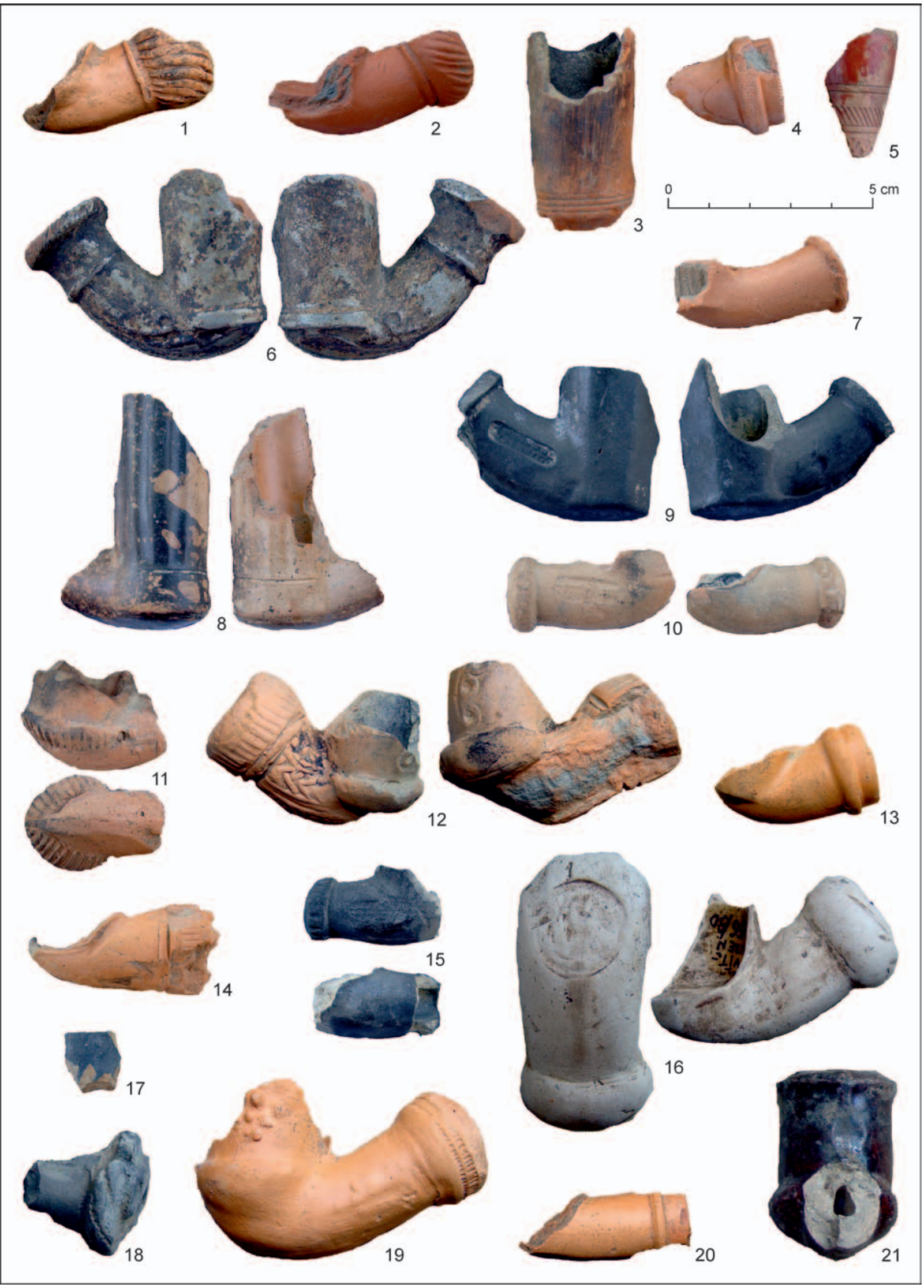

Tab. VI. Nálezy keramických fajok zo Spiša. 1 - Spišská Nová Ves; 2 - Spišský Štiavnik; 3-9 - Spišský Štvrtok; 10, 11 - Svit; 12, 13 - Štrba; 14 - Šuňava; 15 - Výborná; 16 - Vítkovce; 17 - Vlková; 18-21 - Žehra. Foto M. Bielich. 


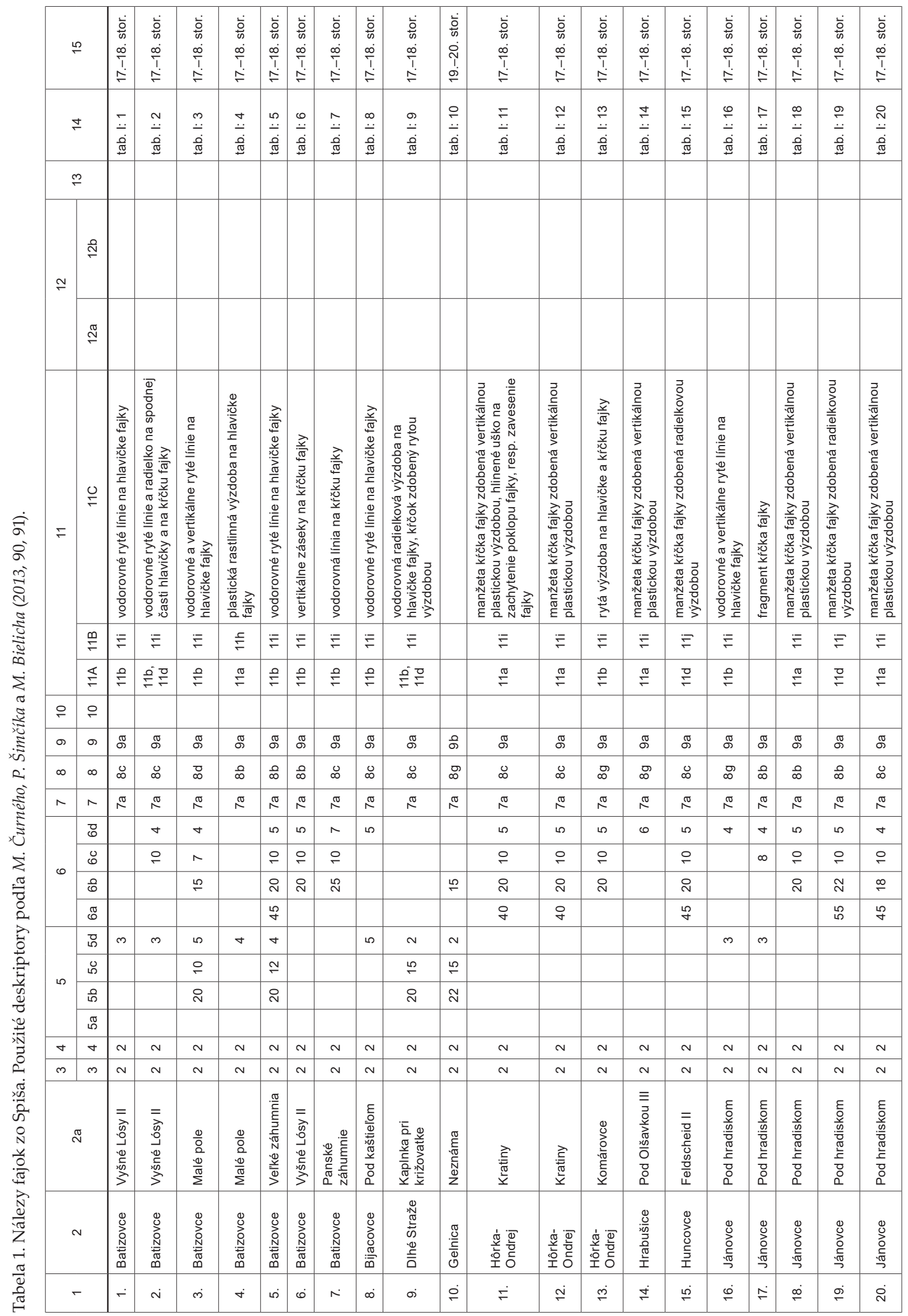




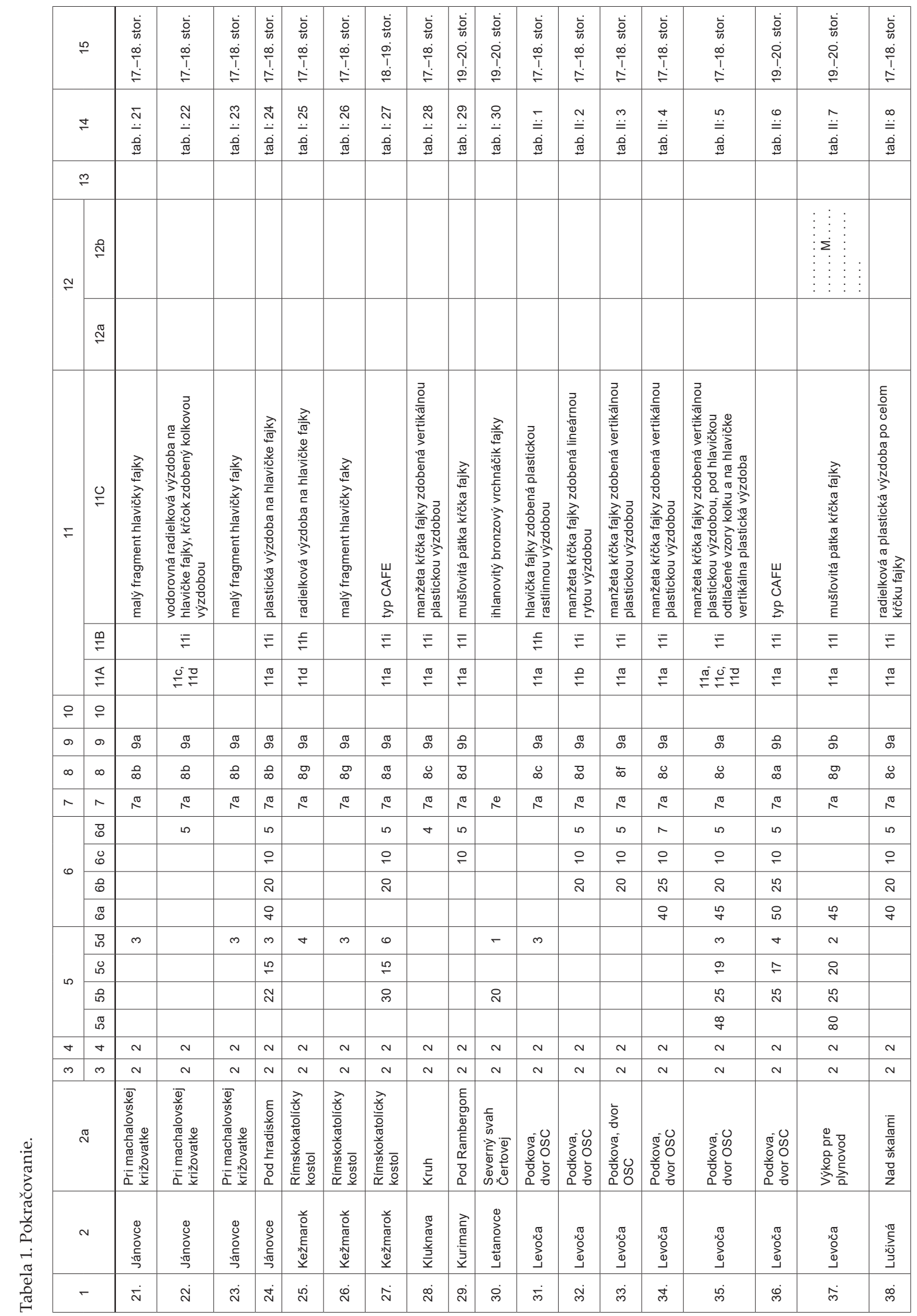




\begin{tabular}{|c|c|c|c|c|c|c|c|c|c|c|c|c|c|c|c|c|c|c|c|}
\hline$\stackrel{\llcorner}{\sim}$ & 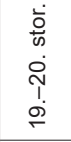 & 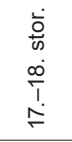 & 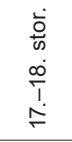 & 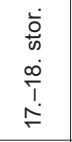 & 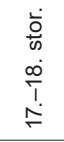 & 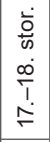 & 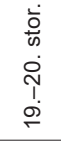 & 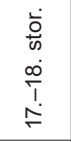 & 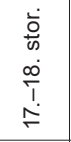 & 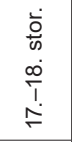 & 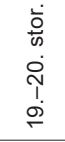 & $\begin{array}{l}\dot{0} \\
5 \\
0 \\
\dot{T} \\
1 \\
\dot{\sigma}\end{array}$ & 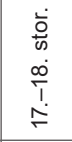 & 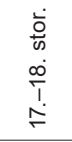 & 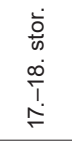 & 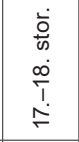 & 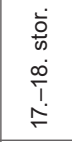 & 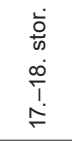 & 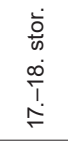 \\
\hline$\stackrel{\square}{\square}$ & 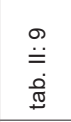 & $\begin{array}{l}\stackrel{ }{0} \\
\stackrel{=}{=} \\
\stackrel{0}{\Phi} \\
\end{array}$ & 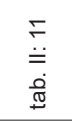 & $\begin{array}{l}\stackrel{N}{\simeq} \\
\stackrel{=}{ \pm} \\
\stackrel{\sigma}{\Phi}\end{array}$ & $\begin{array}{l}\stackrel{m}{ \pm} \\
\stackrel{=}{=} \\
\stackrel{\Phi}{\Phi}\end{array}$ & 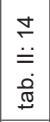 & 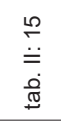 & $\begin{array}{l}\mathscr{\varrho} \\
\stackrel{=}{=} \\
\stackrel{\sigma}{\Phi}\end{array}$ & 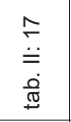 & 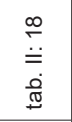 & 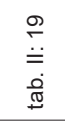 & 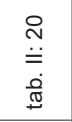 & $\begin{array}{l}\ulcorner \\
\stackrel{\equiv}{=} \\
\stackrel{0}{\Phi}\end{array}$ & $\begin{array}{l}N \\
\stackrel{\equiv}{=} \\
\stackrel{0}{\Phi} \\
\end{array}$ & $\begin{array}{l}m \\
\stackrel{m}{\equiv} \\
\stackrel{0}{\Phi}\end{array}$ & 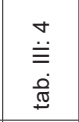 & $\begin{array}{l}\ulcorner \\
\check{.} \\
\stackrel{0}{\Phi}\end{array}$ & $\begin{array}{l}N \\
\stackrel{2}{\geq} \\
\stackrel{\delta}{\Phi}\end{array}$ & $\begin{array}{l}m \\
\stackrel{m}{\geq} \\
\stackrel{0}{\Phi}\end{array}$ \\
\hline$\stackrel{m}{=}$ & & & & & & & & & & & & & & & & & & & \\
\hline$\simeq$ & $\begin{array}{l}\frac{\alpha}{5} \\
\mathbb{N} \\
\mathbb{x} \\
\end{array}$ & & & & & & 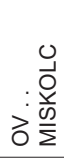 & & & & 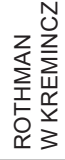 & & & & & & & & \\
\hline$=$ & 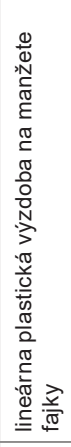 & 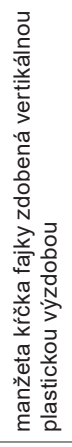 & 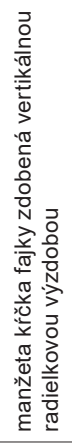 & 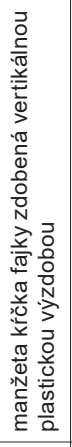 & 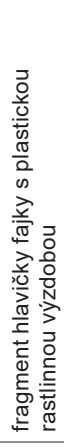 & 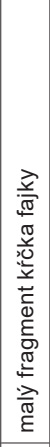 & 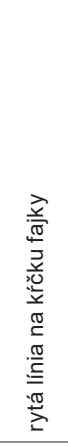 & 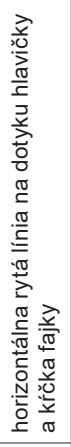 & 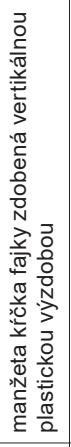 & 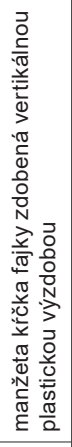 & 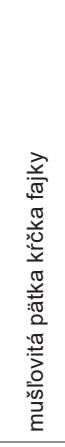 & 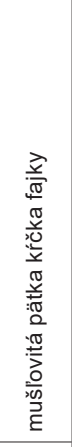 & & 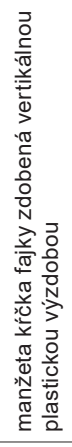 & 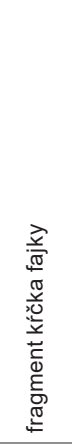 & 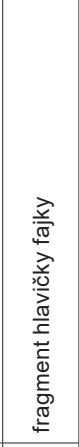 & 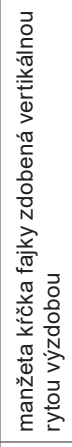 & 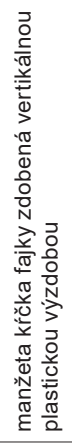 & \\
\hline$\stackrel{m}{\rightleftharpoons}$ & $\bar{E}$ & $\dot{E}$ & $\dot{F}$ & $\bar{F}$ & $\stackrel{5}{F}$ & & $\bar{F}$ & $\dot{F}$ & $\bar{E}$ & $\bar{F}$ & $\bar{F}$ & $E$ & $\bar{F}$ & $\dot{F}$ & & & $\bar{F}$ & $\stackrel{E}{E}$ & \\
\hline$\stackrel{\leftrightarrows}{\rightleftarrows}$ & $\stackrel{\sigma}{=}$ & $\stackrel{\sigma}{=}$ & $\stackrel{\sigma}{\Gamma}$ & $\stackrel{\frac{\pi}{2}}{=}$ & $\stackrel{\pi}{=}$ & & $\stackrel{\rho}{\stackrel{2}{F}}$ & $\stackrel{\rho}{\rightleftharpoons}$ & $\stackrel{\pi}{=}$ & $\stackrel{\frac{\pi}{\digamma}}{\Gamma}$ & $\stackrel{\pi}{=}$ & $\stackrel{\sigma}{=}$ & $\stackrel{\pi}{=}$ & $\stackrel{\sigma}{\Gamma}$ & & & $\stackrel{\rho}{\rightleftharpoons}$ & $\stackrel{\sigma}{=}$ & \\
\hline$\div \quad ㅇ$ & & & & & & & & & & & & & & & & & & & $\stackrel{\circ}{\circ}$ \\
\hline \begin{tabular}{l|l}
$\infty$ & 0 \\
\end{tabular} & ๑ & ภ & ๑ & నూ & ه & \% & ه & ఠ & న & న & क & कㅇ & ه & ภ & க & ๑ & ه & ภ & ภ \\
\hline \begin{tabular}{l|l}
$\infty$ & $\infty$ \\
\end{tabular} & $\overleftarrow{\infty}$ & $\infty$ & $\infty$ & $\infty$ & $\infty$ & $\infty$ & $\infty$ & $\overleftarrow{\infty}$ & $\infty$ & $\infty$ & $\infty$ & $\stackrel{\infty}{\infty}$ & $\stackrel{\infty}{\infty}$ & $\infty$ & ¿ & ळ & $\stackrel{\square}{\infty}$ & $\infty$ & ळ \\
\hline \begin{tabular}{l|l} 
& $\wedge$ \\
\end{tabular} & ก & ๘ & ก & ก & $\stackrel{\pi}{\pi}$ & $\pi$ & ก & $\stackrel{\pi}{\pi}$ & $\stackrel{\pi}{\pi}$ & $\stackrel{1}{\check{1}}$ & ๘ & ก & ๙ & $\stackrel{\pi}{\pi}$ & 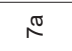 & 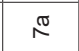 & $\approx$ & $\approx$ & ๘ \\
\hline : & is & is & $\checkmark$ & is & & & $\nabla$ & is & $\wedge$ & 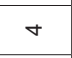 & $\wedge$ & & $\circ$ & $\infty$ & $\checkmark$ & & $\infty$ & م & م \\
\hline$\stackrel{0}{0}$ & $\stackrel{m}{=}$ & 우 & 우 & 우 & & & & $\stackrel{\circ}{\circ}$ & $\stackrel{\circ}{\circ}$ & $\stackrel{\circ}{\circ}$ & $\stackrel{\circ}{\circ}$ & & $\stackrel{\circ}{\circ}$ & $\stackrel{\circ}{\circ}$ & $\simeq$ & & $\stackrel{\circ}{\circ}$ & 우 & 우 \\
\hline $\begin{array}{lll}0 & 8 \\
\end{array}$ & $\tilde{N}$ & i & & $\stackrel{2}{2}$ & & & & i & $\stackrel{\sim}{\sim}$ & $\stackrel{\infty}{\sim}$ & $\stackrel{\sim}{\sim}$ & & i & i & i & & i & i & $\tilde{N}$ \\
\hline ह & 우 & \& & & & & & & & & $\stackrel{m}{\infty}$ & in & & 8 & g & & & & 우 & q \\
\hline : & & & & & $m$ & 6 & $\nabla$ & $m$ & & & & $m$ & & & & $m$ & & & \\
\hline i & & & & & & & & & & & & & & & & & & & \\
\hline की & & & & & & & & & & & & & & & & & & & \\
\hline డ็ & & & & & & & & & & & & & & & & & & & \\
\hline \begin{tabular}{l|l} 
& $\sigma$ \\
\end{tabular} & $N$ & $N$ & $N$ & $N$ & $N$ & $N$ & $N$ & $N$ & $N$ & $N$ & $\sim$ & $N$ & $N$ & $N$ & $N$ & N & $N$ & $N$ & $N$ \\
\hline \begin{tabular}{l|l}
$m$ & $m$ \\
\end{tabular} & $N$ & $N$ & $N$ & $N$ & $N$ & $N$ & $N$ & $N$ & $N$ & $N$ & $\sim$ & $N$ & $N$ & $N$ & $N$ & N & $N$ & $N$ & $N$ \\
\hline$\stackrel{\pi}{\text { ก็ }}$ & 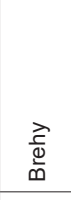 & $\begin{array}{l}\overrightarrow{\vec{E}} \\
\frac{\tilde{\omega}}{\dot{\omega}}\end{array}$ & 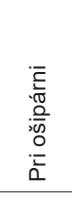 & 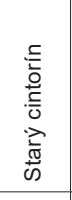 & 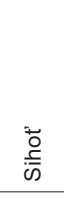 & 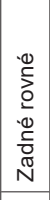 & 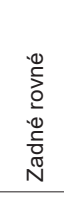 & 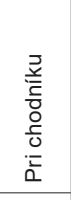 & 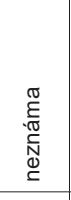 & 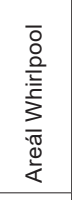 & 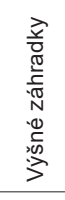 & 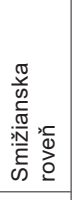 & 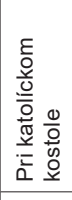 & 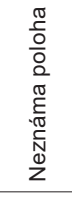 & 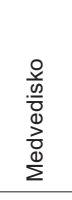 & 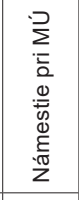 & 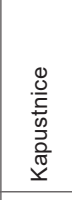 & 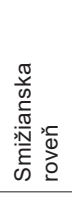 & 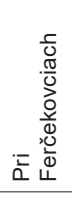 \\
\hline$N$ & 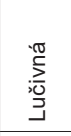 & $\sum_{j=0}^{\infty}$ & 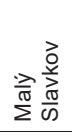 & $\begin{array}{l}\frac{\pi}{0} \\
\frac{0}{0} \\
\frac{0}{0}\end{array}$ & 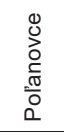 & 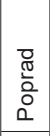 & $\begin{array}{l}\frac{\pi}{0} \\
\frac{\pi}{2} \\
0 \\
\end{array}$ & $\begin{array}{l}0 \\
\frac{\pi}{2} \\
\frac{0}{0} \\
0\end{array}$ & $\begin{array}{l}\frac{\sigma}{0} \\
\frac{\pi}{2} \\
0 \\
\end{array}$ & $\begin{array}{l}0 \\
\frac{\pi}{2} \\
0 \\
0 \\
\end{array}$ & $\begin{array}{l}\frac{\sigma}{0} \\
\frac{\bar{\sigma}}{2} \\
0\end{array}$ & 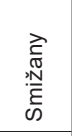 & 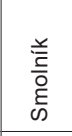 & 䖪 & 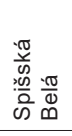 & 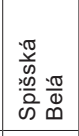 & 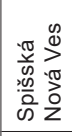 & 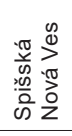 & 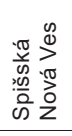 \\
\hline- & में & $\dot{q}$ & $\dot{\sigma}$ & ช่ & $\dot{g}$ & $\dot{J}$ & 字 & $\dot{g}$ & $\dot{f}$ & $\stackrel{\infty}{+}$ & ஓே & in & $\dot{\text { in }}$ & ชิ & ڤึ & :ُ & 官 & in & เి \\
\hline
\end{tabular}




\begin{tabular}{|c|c|c|c|c|c|c|c|c|c|c|c|c|c|c|c|c|c|}
\hline 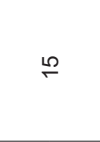 & 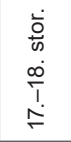 & 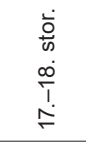 & 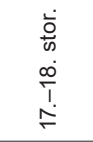 & 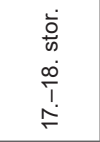 & 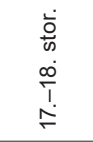 & 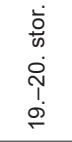 & 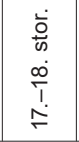 & 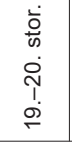 & 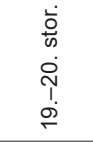 & 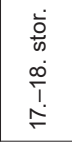 & 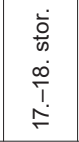 & 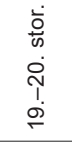 & 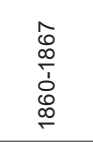 & 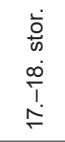 & 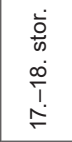 & 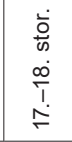 & 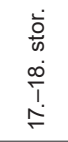 \\
\hline$\stackrel{\square}{ }$ & 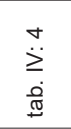 & 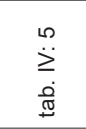 & 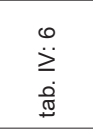 & 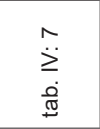 & $\begin{array}{l}\infty \\
\stackrel{\geq}{ \pm} \\
\stackrel{0}{\Phi} \\
\Phi\end{array}$ & 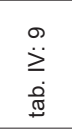 & 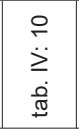 & 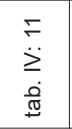 & 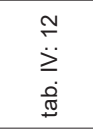 & $\begin{array}{l}\stackrel{m}{\check{m}} \\
\stackrel{0}{0} \\
\dot{0}\end{array}$ & 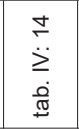 & 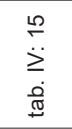 & 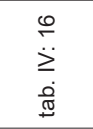 & 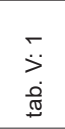 & 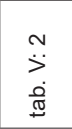 & $\begin{array}{l}m \\
\stackrel{m}{>} \\
\stackrel{0}{\Phi}\end{array}$ & 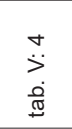 \\
\hline$\stackrel{m}{=}$ & & & & & & & & & & & & & & & & & \\
\hline$\simeq$ & & & & & & & & & & & & $\vdots N$ & 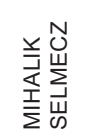 & & & & \\
\hline$\stackrel{\mathbb{N}}{\sim}$ & & & & & & & & & 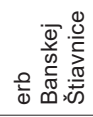 & & & & 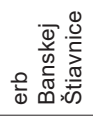 & & & & \\
\hline$\stackrel{0}{\rightleftharpoons}$ & 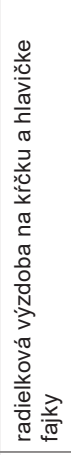 & 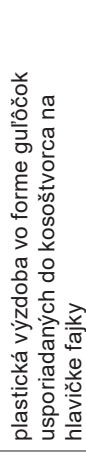 & 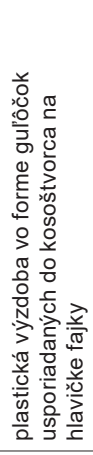 & 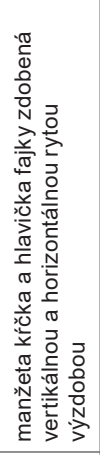 & 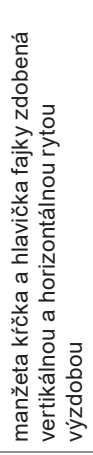 & 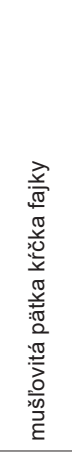 & 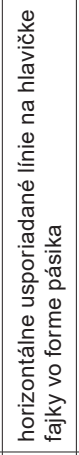 & 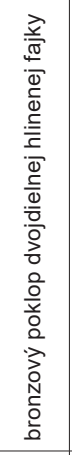 & 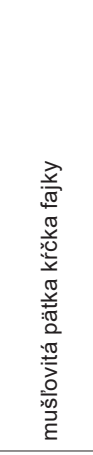 & 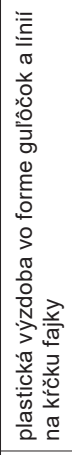 & 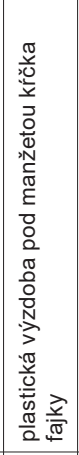 & 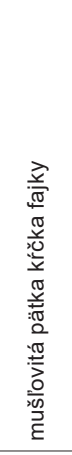 & 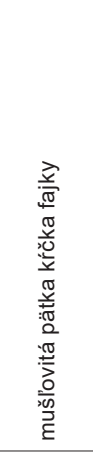 & 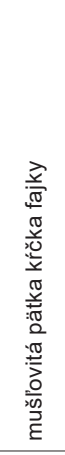 & 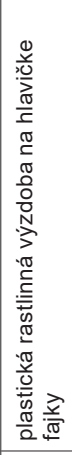 & 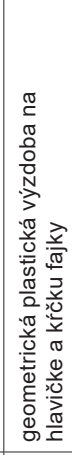 & 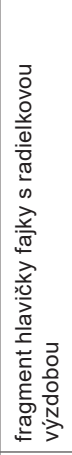 \\
\hline$\stackrel{m}{\rightleftharpoons}$ & $\Xi$ & $F$ & $\Xi$ & $\Xi$ & $\Xi$ & $\bar{F}$ & $\bar{E}$ & & $\bar{E}$ & $\bar{E}$ & $F$ & $\equiv$ & $E$ & $\stackrel{\xi}{\check{E}}$ & $\stackrel{F}{F}$ & $\stackrel{\pi}{=}$ & 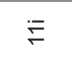 \\
\hline$\stackrel{\Xi}{!}$ & $\stackrel{ }{=}$ & $\stackrel{\sigma}{=}$ & $\stackrel{\sigma}{=}$ & $\stackrel{\rho}{F}$ & $\stackrel{\circ}{F}$ & $\stackrel{\sigma}{=}$ & $\stackrel{\sigma}{=}$ & & $\stackrel{\sigma}{=}$ & $\stackrel{\sigma}{=}$ & $\stackrel{\text { ㅁ }}{=}$ & $\stackrel{\sigma}{=}$ & $\stackrel{\sigma}{=}$ & $\stackrel{\sigma}{=}$ & $\stackrel{\sigma}{=}$ & $\stackrel{\pi}{=}$ & $\stackrel{ }{=}$ \\
\hline$\div \quad ㅇ$ & & & & & & & & & & & & & & & & & \\
\hline \begin{tabular}{l|l} 
& 0 \\
\end{tabular} & \% & \% & ه & \% & ه & ஃ & \% & & क & ه & ه & ㅇ & के & ه & ه & ه & \% \\
\hline \begin{tabular}{l|l}
$\infty$ & $\infty$
\end{tabular} & ○ & $\stackrel{\infty}{\infty}$ & $\stackrel{\infty}{\infty}$ & $\stackrel{\circ}{\infty}$ & $\stackrel{\infty}{\infty}$ & $\infty$ & ळ & & $\infty$ & $\overleftarrow{\infty}$ & 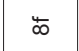 & $\stackrel{\infty}{\infty}$ & চ & $\stackrel{\infty}{\infty}$ & $\infty$ & $\underset{\infty}{\infty}$ & $\stackrel{\infty}{\infty}$ \\
\hline \begin{tabular}{l|l}
$\wedge$ & $\wedge$ \\
\end{tabular} & ๘ & న & ๘ & ๘ & ๘ & ๘ & ๘ & ก & న & న & ๘ & ๘ & ๘ & 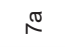 & ๘ & ๘ & ก \\
\hline 8 & is & & م & $\infty$ & ـ & ю & & & م & $\wedge$ & م & م & $r$ & & & $\sim$ & \\
\hline 8 & 우 & & & 우 & 우 & 우 & & & 우 & 우 & 우 & 우 & 우 & & & 우 & \\
\hline $\begin{array}{lll}0 & 8 \\
\end{array}$ & i & & & i & i & i & & & & $\stackrel{\sim}{\sim}$ & i & i & $\stackrel{\sim}{\sim}$ & & & $\stackrel{\llcorner}{\llcorner}$ & \\
\hline ర్ & in & & & q & q & & & & & 요 & q & & is & & & & \\
\hline 뭉 & & m & + & $N$ & N & $m$ & 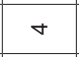 & & m & $m$ & m & $m$ & م & $\sim$ & $m$ & $\sim$ & $m$ \\
\hline$\stackrel{\circ}{\circ}$ & & $\stackrel{0}{\circ}$ & & & & กิ & & & $\stackrel{2}{\llcorner}$ & i & $\stackrel{2}{\llcorner}$ & $\stackrel{\circ}{\llcorner}$ & $\stackrel{2}{\llcorner}$ & & & $\stackrel{\circ}{\llcorner}$ & \\
\hline iी & & N & & & & $\stackrel{\sim}{N}$ & & & i & $\stackrel{\sim}{N}$ & i & $\stackrel{2}{N}$ & $\stackrel{2}{\sim}$ & & & 尺 & \\
\hline డ็ & & q & & & & & & & & & & & & & & & \\
\hline \begin{tabular}{l|l}
$\sigma$ & $\sigma$
\end{tabular} & $N$ & $N$ & $N$ & $N$ & $N$ & $N$ & $N$ & $N$ & $N$ & $N$ & N & $N$ & $N$ & $N$ & $N$ & $N$ & $N$ \\
\hline \begin{tabular}{l|l}
$m$ & $m$ \\
\end{tabular} & $N$ & $N$ & $N$ & $N$ & $N$ & $N$ & $N$ & $N$ & $N$ & N & N & $N$ & $N$ & $N$ & $N$ & $\sim$ & $N$ \\
\hline ึำ & 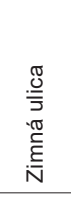 & 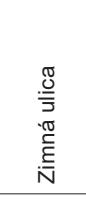 & 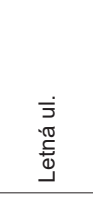 & 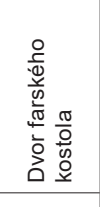 & 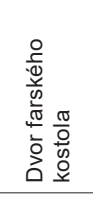 & 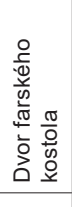 & 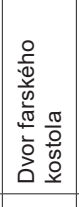 & 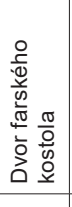 & 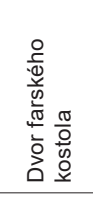 & 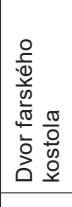 & 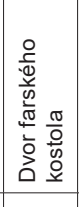 & 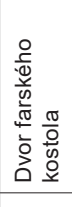 & 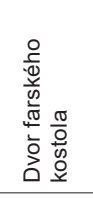 & 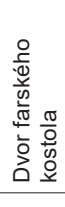 & 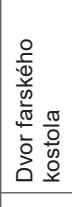 & 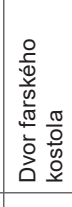 & 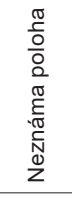 \\
\hline$N$ & 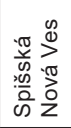 & 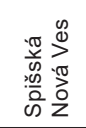 & 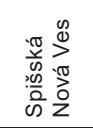 & 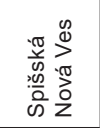 & 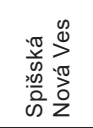 & 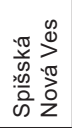 & 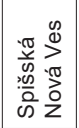 & 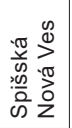 & 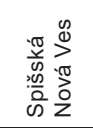 & 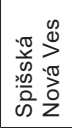 & 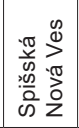 & 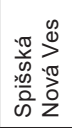 & 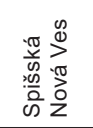 & 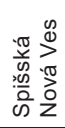 & 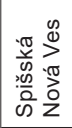 & 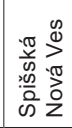 & 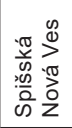 \\
\hline- & $\stackrel{\infty}{\infty}$ & ஜீ & $\dot{\theta}$ & $\dot{6}$ & ชิ & ஜ் & ذீ & ம் & $\ddot{\circ}$ & $\hat{\emptyset}$ & $\infty^{\prime}$ & ச் & i & $\dot{r}$ & $\stackrel{N}{N}$ & $\stackrel{M}{\wedge}$ & 玄 \\
\hline
\end{tabular}




\begin{tabular}{|c|c|c|c|c|c|c|c|c|c|c|c|c|c|c|c|c|c|}
\hline$\stackrel{2}{2}$ & 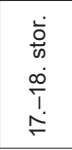 & 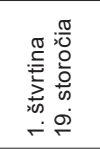 & 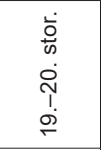 & 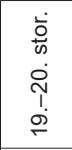 & 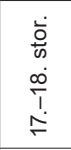 & 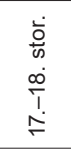 & 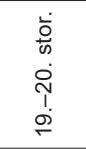 & 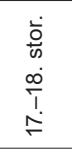 & 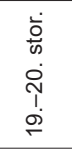 & 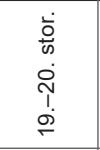 & 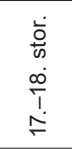 & 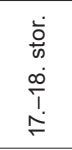 & 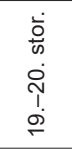 & 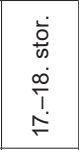 & 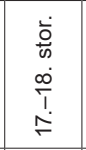 & 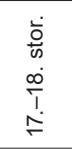 & 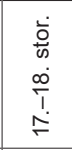 \\
\hline 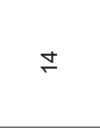 & 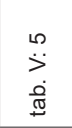 & $\begin{array}{l}0 \\
\stackrel{0}{\circ} \\
\stackrel{0}{\Phi]}\end{array}$ & 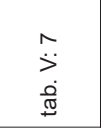 & 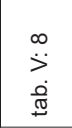 & 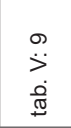 & 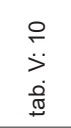 & 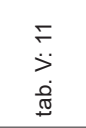 & 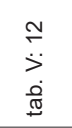 & 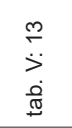 & 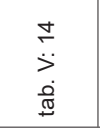 & 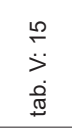 & 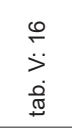 & 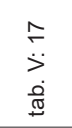 & 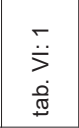 & 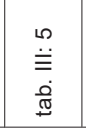 & 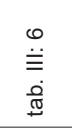 & 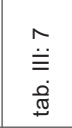 \\
\hline \multicolumn{18}{|l|}{$\stackrel{m}{=}$} \\
\hline \multirow[t]{2}{*}{$\simeq$} & & 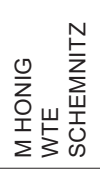 & & 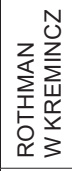 & & & $\vdots \begin{array}{c}\stackrel{N}{\frac{N}{z}} \\
\vdots \\
\vdots \\
\vdots\end{array}$ & & & 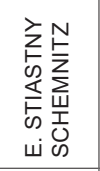 & & & & & & & \\
\hline & & 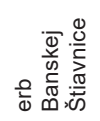 & 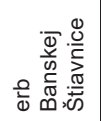 & 亩 & & & 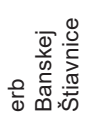 & & & 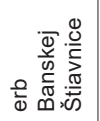 & & & & & & & \\
\hline$\stackrel{0}{F}$ & 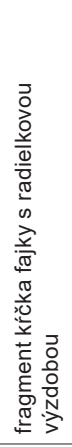 & 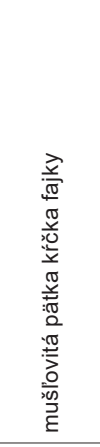 & 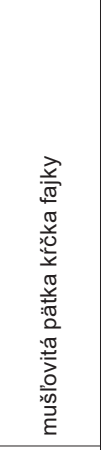 & 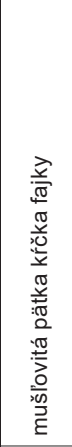 & 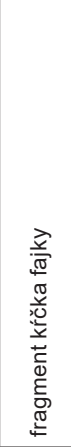 & 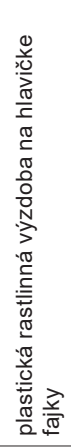 & 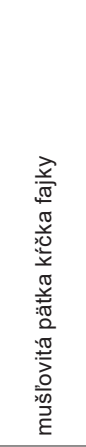 & 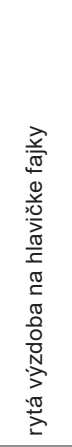 & 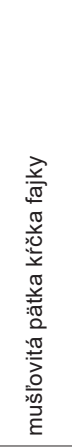 & 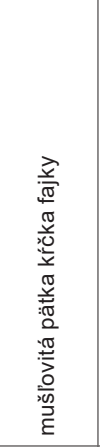 & 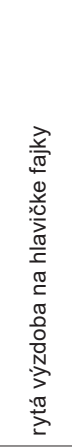 & 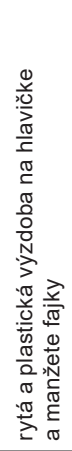 & 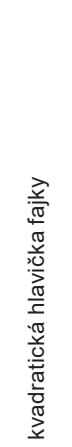 & 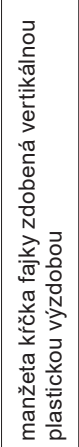 & 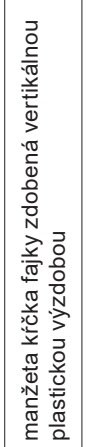 & 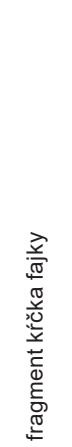 & 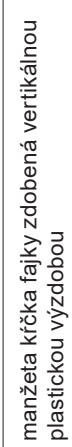 \\
\hline$\stackrel{m}{ }$ & $\bar{F}$ & $\bar{F}$ & $\Xi$ & $\bar{F}$ & & $\stackrel{\rho}{\risingdotseq}$ & $\bar{F}$ & 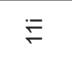 & $\bar{F}$ & $\bar{E}$ & $\bar{E}$ & $\bar{F}$ & & 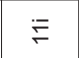 & 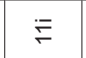 & 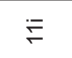 & $\bar{F}$ \\
\hline 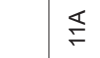 & $\stackrel{\rho}{F}$ & $\stackrel{\pi}{\rightleftharpoons}$ & $\stackrel{\pi}{\rightleftharpoons}$ & $\stackrel{\sigma}{\rightleftharpoons}$ & & $\stackrel{\sigma}{\rightleftharpoons}$ & $\stackrel{\sigma}{=}$ & $\stackrel{2}{\rightleftharpoons}$ & $\stackrel{\sigma}{\rightleftharpoons}$ & $\stackrel{\sigma}{=}$ & $\stackrel{\rho}{F}$ & 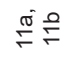 & & $\stackrel{\rho}{ }$ & $\stackrel{\pi}{=}$ & $\stackrel{\pi}{\rightleftharpoons}$ & $\stackrel{\pi}{\rightleftharpoons}$ \\
\hline$\circ \div$ & & & & & & & & & & & & & 훙 & & & & \\
\hline \begin{tabular}{l|l}
0 & 0
\end{tabular} & ه & क & ㅇ & ค & ه & ه్ & क & ภ็ & क & ㅇ & ه & ه & ㅇ & ภ & ภ็ & ภ็ & ఠ \\
\hline \begin{tabular}{l|l}
$\infty$ & $\infty$
\end{tabular} & $\stackrel{\infty}{\infty}$ & 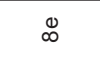 & $\stackrel{\square}{\infty}$ & D & $\stackrel{\infty}{\infty}$ & $\stackrel{\infty}{\infty}$ & $\stackrel{\infty}{\infty}$ & $\stackrel{\infty}{\infty}$ & ळ & $\stackrel{\infty}{\infty}$ & $\stackrel{\circ}{\infty}$ & $\stackrel{\circ}{\infty}$ & $\stackrel{\infty}{\infty}$ & 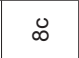 & $\overleftarrow{\infty}$ & ¿ & $\stackrel{\infty}{\infty}$ \\
\hline \begin{tabular}{l|l} 
& $\wedge$ \\
\end{tabular} & $\stackrel{乛}{\curvearrowright}$ & 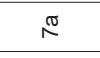 & $\stackrel{\pi}{\pi}$ & 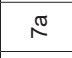 & $\stackrel{\pi}{\curvearrowright}$ & $\stackrel{2}{\curvearrowleft}$ & 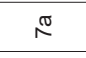 & $\stackrel{10}{\kappa}$ & $\stackrel{20}{\check{2}}$ & $\stackrel{\pi}{2}$ & $\stackrel{\pi}{\curvearrowright}$ & $\stackrel{2}{\pi}$ & ก & 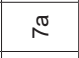 & 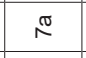 & ก & $\stackrel{\pi}{\curvearrowright}$ \\
\hline 8 & ๑ & $\Lambda$ & $\Lambda$ & ம & ๑ & ம & ம & & ம & เ & เ & \llcorner & & $\infty$ & $\infty$ & เ & ๑ \\
\hline $\begin{array}{ll}0 \\
0\end{array}$ & $\stackrel{\circ}{\circ}$ & 우 & 우 & $\circ$ & 웅 & $\infty$ & 우 & & 우 & 우 & 웅 & 웅 & & 우 & 우 & 우 & 우 \\
\hline $\begin{array}{lll}0 & 8 \\
\end{array}$ & i & $\stackrel{2}{N}$ & & N & ก & & i & & i & i & i & i & & i & i & & ণ \\
\hline 8 & & in & & \& & & & & & & in & q & \& & & o & & 우 & \\
\hline i & & & & & & $m$ & $m$ & $m$ & $m$ & $m$ & $m$ & $\sim$ & $N$ & & & & \\
\hline م & & & & & & হి & i & & i & i & & ì & ì & & & & \\
\hline ᄂ & & & & & & $\stackrel{\text { N }}{ }$ & $\stackrel{2}{\sim}$ & & $\stackrel{2}{N}$ & $\stackrel{\mathscr{N}}{\sim}$ & & $\stackrel{2}{\sim}$ & $\stackrel{2}{N}$ & & & & \\
\hline ஸீ & & & & & & & & & & & & & & & & & \\
\hline \begin{tabular}{l|l} 
& $\sigma$
\end{tabular} & $\sim$ & $N$ & $N$ & $\sim$ & $\sim$ & $\sim$ & $N$ & $N$ & $N$ & N & $\sim$ & $\sim$ & $\sim$ & N & $N$ & $N$ & $\sim$ \\
\hline \begin{tabular}{l|l}
$m$ & $m$ \\
\end{tabular} & $N$ & $N$ & $N$ & $N$ & $N$ & $N$ & $N$ & $N$ & N & $N$ & $N$ & $N$ & $N$ & N & $N$ & N & $N$ \\
\hline న & 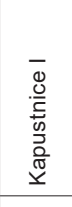 & 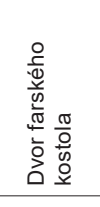 & 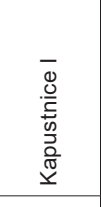 & 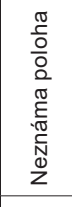 & 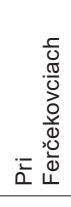 & 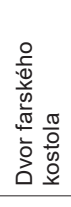 & 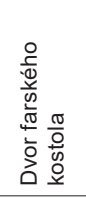 & 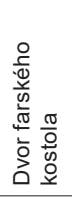 & 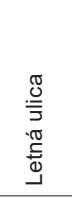 & 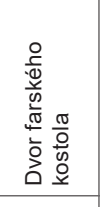 & 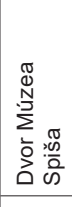 & 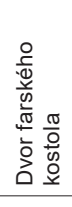 & 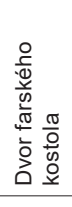 & 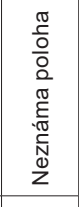 & 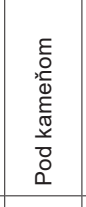 & 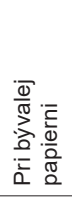 & 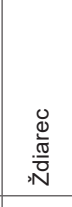 \\
\hline$N$ & 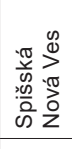 & 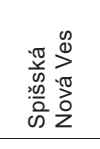 & 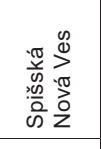 & 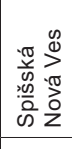 & 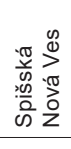 & 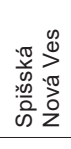 & 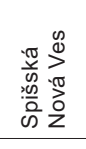 & 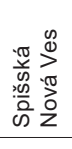 & 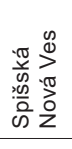 & 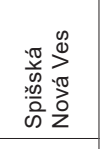 & 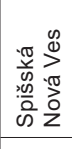 & 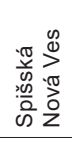 & 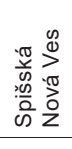 & 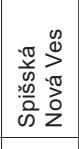 & 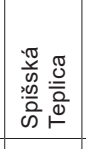 & 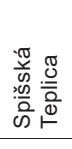 & 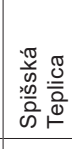 \\
\hline- & $\stackrel{\rho}{R}$ & $\stackrel{8}{\gtrless}$ & 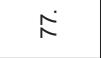 & $\stackrel{\infty}{\wedge}$ & $\stackrel{\rho}{R}$ & $\dot{\infty}$ & $\dot{\infty}$ & ஸ் & $\stackrel{\infty}{\infty}$ & मे & ஜ் & $\stackrel{\infty}{\infty}$ & $\stackrel{\infty}{\infty}$ & $\underset{\infty}{\infty}$ & ळ் & த் & $\dot{\sigma}$ \\
\hline
\end{tabular}




\begin{tabular}{|c|c|c|c|c|c|c|c|c|c|c|c|c|c|c|c|c|c|c|}
\hline 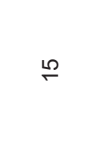 & 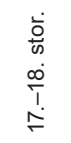 & 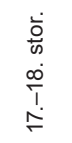 & 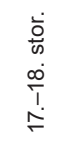 & 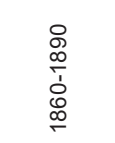 & 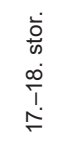 & 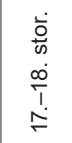 & 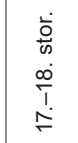 & 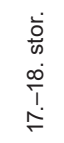 & 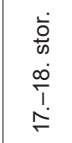 & 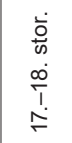 & 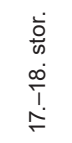 & 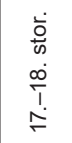 & 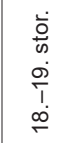 & 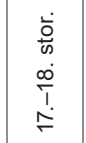 & 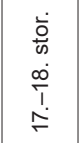 & 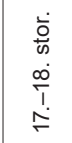 & 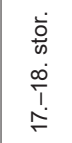 & 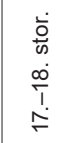 \\
\hline 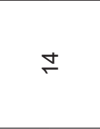 & $\begin{array}{l}\infty \\
\stackrel{\infty}{=} \\
\stackrel{\equiv}{0} \\
\dot{0}\end{array}$ & 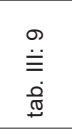 & 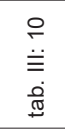 & 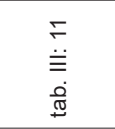 & 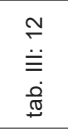 & $\begin{array}{l}\stackrel{m}{m} \\
\stackrel{\equiv}{\equiv} \\
\stackrel{0}{\Phi}\end{array}$ & 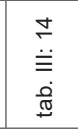 & $\begin{array}{l}\stackrel{\circ}{\mathscr{n}} \\
\stackrel{=}{=} \\
\stackrel{\sigma}{\Phi}\end{array}$ & 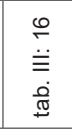 & 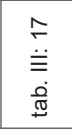 & 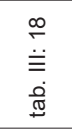 & 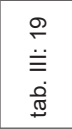 & 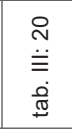 & 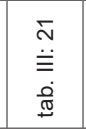 & 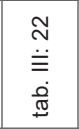 & 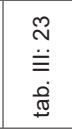 & $\begin{array}{l}\stackrel{+}{N} \\
\stackrel{\equiv}{=} \\
\stackrel{\Phi}{\Phi}\end{array}$ & 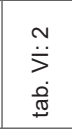 \\
\hline$\underline{m}$ & & & & & & & & & & & & & & & & & & \\
\hline$\simeq$ & & & & 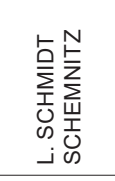 & & & & & & & & & 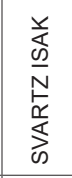 & & & & & \\
\hline$\stackrel{\mathbb{N}}{\sim}$ & & & & 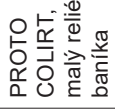 & & & & & & & & & & & & & & \\
\hline$\stackrel{O}{E}$ & 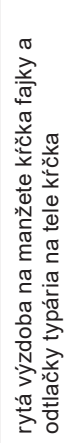 & 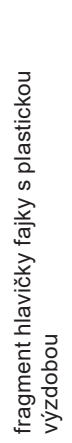 & 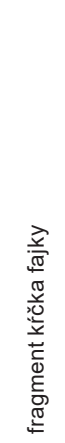 & 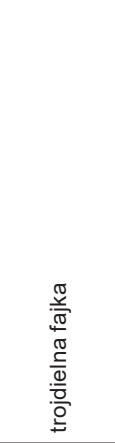 & 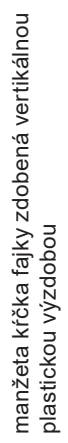 & 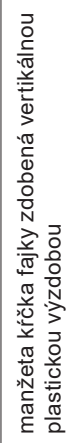 & 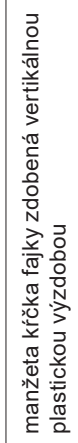 & 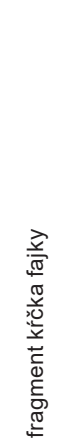 & 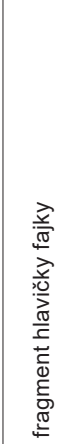 & 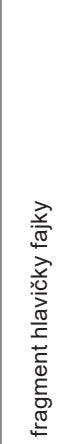 & 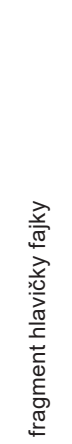 & 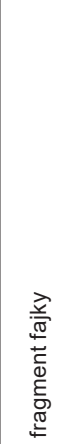 & 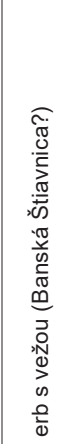 & 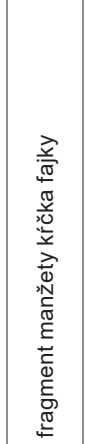 & 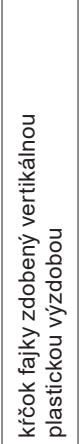 & 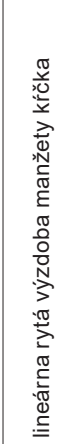 & 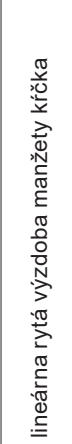 & 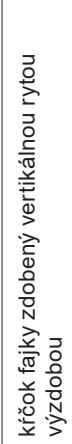 \\
\hline$\stackrel{p}{r}$ & $\bar{F}$ & $F$ & $\bar{F}$ & & $\bar{F}$ & $\bar{F}$ & $\bar{F}$ & & $\bar{F}$ & $\bar{F}$ & & $\bar{F}$ & & $\bar{F}$ & 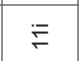 & $\bar{F}$ & $\bar{F}$ & $\bar{F}$ \\
\hline$\stackrel{\Xi}{\leftrightarrows}$ & $\stackrel{\sigma}{\rightleftharpoons}$ & $\stackrel{\sigma}{\rightleftharpoons}$ & $\stackrel{\pi}{=}$ & & $\stackrel{\sigma}{\rightleftharpoons}$ & $\stackrel{\sigma}{\rightleftharpoons}$ & $\stackrel{\pi}{\stackrel{\circ}{r}}$ & & $\stackrel{ }{ }$ & $\stackrel{\sigma}{=}$ & & $\stackrel{\rho}{F}$ & & $\stackrel{ }{ }$ & $\stackrel{\widetilde{\sigma}}{=}$ & $\stackrel{\rho}{F}$ & $\stackrel{\rho}{F}$ & $\stackrel{\rho}{\rightleftharpoons}$ \\
\hline$\circ \div$ & 웅 & & & & $\stackrel{\sigma}{\stackrel{\sigma}{\circ}}$ & & & & & & & & & & & & & \\
\hline \begin{tabular}{l|l}
$\sigma$ & 0
\end{tabular} & ภ็ & ภ็ & ळ & 으 & ภ็ & வ & ๑็ & ภீ & ळూ & ภீ & ฮ็ & ภீ & の & ه & வ็ & ळూ & வீ & దూ \\
\hline \begin{tabular}{l|l} 
& $\infty$
\end{tabular} & $\underset{\infty}{\infty}$ & $\infty$ & $\stackrel{\circ}{\infty}$ & $\infty \varnothing$ & $\overleftarrow{\infty}$ & $\stackrel{\circ}{\infty}$ & $\stackrel{0}{\infty}$ & $\check{\infty}$ & ळ & $\stackrel{\infty}{\infty}$ & $\underset{\infty}{\infty}$ & $\overleftrightarrow{\infty}$ & $\stackrel{\circ}{\infty}$ & $\stackrel{\infty}{\infty}$ & $\infty$ & $\infty$ & $\stackrel{\infty}{\infty}$ & $\stackrel{\square}{\square}$ \\
\hline \begin{tabular}{l|l} 
& $\wedge$
\end{tabular} & $\approx$ & ๙ & $\stackrel{\sigma}{\kappa}$ & $\approx$ & $\stackrel{\pi}{\sim}$ & ๙ & ๙ & 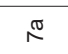 & 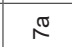 & $\approx$ & 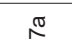 & $\approx$ & $\pi$ & 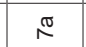 & $\pi$ & 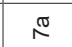 & $\pi$ & 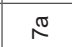 \\
\hline 8 & $\infty$ & & $m$ & $m$ & $m$ & $\sigma$ & م & م & & & & $m$ & n & ما & $\sigma$ & ما & ما & م \\
\hline 8 & 우 & & $r$ & $\lambda$ & 웅 & 우 & 웅 & & & & & $\Lambda$ & 우 & & $r$ & 우 & 움 & 웅 \\
\hline$\frac{10}{80}$ & $\stackrel{\mathscr{N}}{\sim}$ & & $\dot{\sigma}$ & I & ₹ & & ก & & & & & $\stackrel{\circ}{\circ}$ & ㅇ & & $\stackrel{0}{\llcorner}$ & 尺ิ & 尺 & ฉิ \\
\hline ఠ్ & & & & & q & q & & & & & & q & in & & q & \& & 요 & g \\
\hline 뭉 & & เ & & $r$ & & & & & $\sigma$ & $m$ & $m$ & $\sim$ & & & & & & \\
\hline in & & & & $\stackrel{\circ}{\circ}$ & & & & & & & & 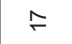 & & & & & & \\
\hline 6) & & & & $\stackrel{\text { a }}{ }$ & & & & & & & & i & & & & & & \\
\hline 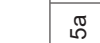 & & & & q & & & & & & & & & & & & & & \\
\hline \begin{tabular}{l|l}
$\sigma$ & $\sigma$
\end{tabular} & $N$ & $N$ & $N$ & $m$ & $\sim$ & $\sim$ & $N$ & $N$ & $\sim$ & $\sim$ & $N$ & $\sim$ & $N$ & $N$ & $N$ & $N$ & $\sim$ & $\sim$ \\
\hline \begin{tabular}{l|l}
$m$ & $m$ \\
\end{tabular} & $N$ & $N$ & $\sim$ & $N$ & $\sim$ & $\sim$ & $N$ & $N$ & $\sim$ & $N$ & $N$ & $\sim$ & $N$ & $\sim$ & $N$ & $\sim$ & $N$ & $\sim$ \\
\hline న్ & 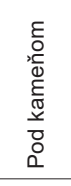 & 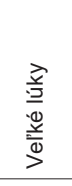 & 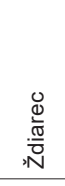 & 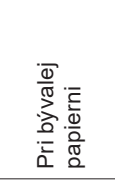 & 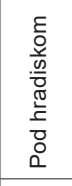 & 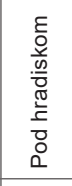 & 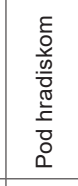 & 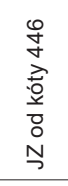 & 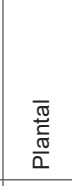 & 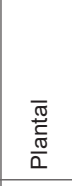 & $\begin{array}{l}\overline{\bar{\sigma}} \\
\frac{\mathrm{w}}{\mathrm{w}} \\
\frac{\mathrm{w}}{\mathrm{a}}\end{array}$ & $\begin{array}{l}\frac{\bar{\pi}}{\frac{\pi}{5}} \\
\frac{\pi}{0}\end{array}$ & 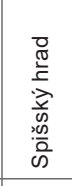 & 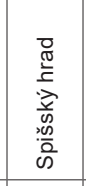 & $\begin{array}{l}\frac{\pi}{\sigma} \\
\frac{\pi}{2} \\
\frac{2}{0} \\
\frac{0}{0} \\
\frac{0}{2} \\
0\end{array}$ & 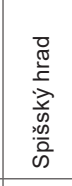 & 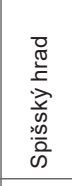 & 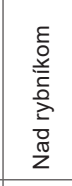 \\
\hline$N$ & 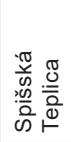 & 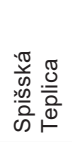 & 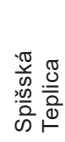 & 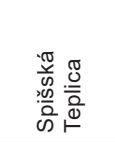 & 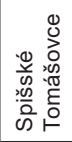 & 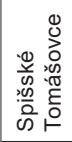 & 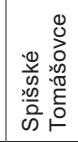 & 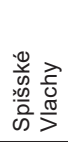 & 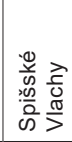 & 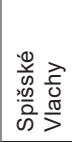 & 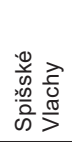 & 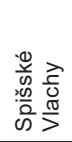 & 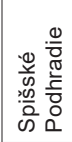 & 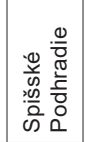 & 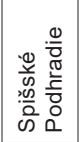 & 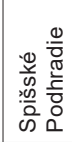 & 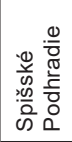 & 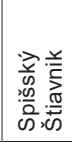 \\
\hline- & ๙่ & ळ் & க் & ப் & $\dot{8}$ & $\dot{\sigma}$ & $\stackrel{\infty}{\infty}$ & ஜ் & ஜ் & $\dot{\circ}$ & 욤 & $\stackrel{\rho}{\circ}$ & $\stackrel{\stackrel{\leftrightarrow}{\circ}}{\sim}$ & $\stackrel{\leftrightarrow}{\circ}$ & $\stackrel{\circ}{\circ}$ & $\stackrel{\hat{o}}{\circ}$ & $\stackrel{\infty}{\circ}$ & ஜ் \\
\hline
\end{tabular}




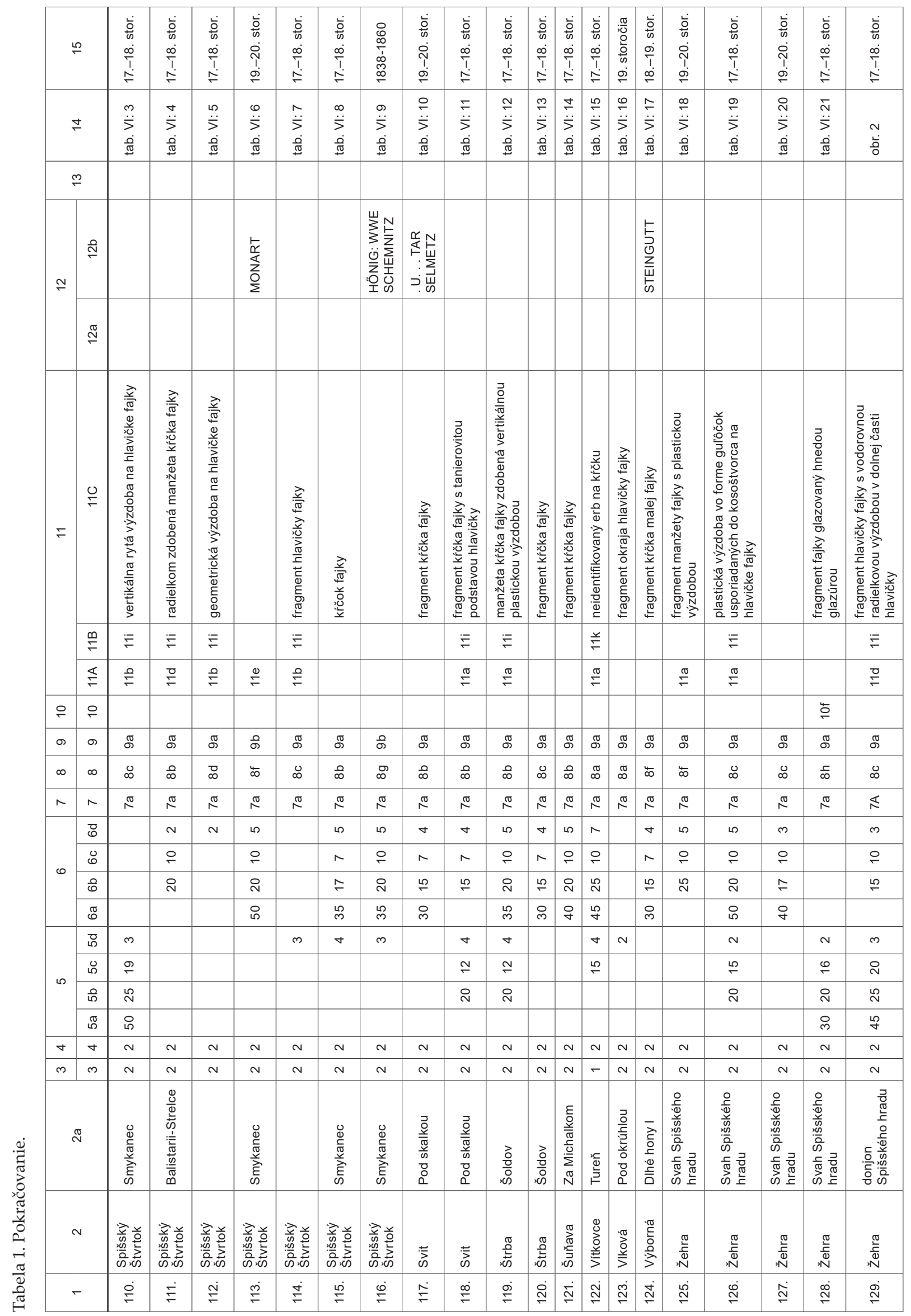




\title{
Clay Pipes from Spiš Region
}

\author{
Mário Bielich - Marián Soják
}

Resume

The aim of this contribution is a basic analysis of a miniature postmedieval ceramic artefact - pipe from the region of Spiš. The finds come from the depository of the department of the Institute of Archaeology of SAS in Spišská Nová Ves. There are 127 fragments of bipartite clay pipes and two metal parts of pipes. The pipes arrived in the depository of the IA SAS mainly by means of surface collections of F. Javorský and M. Soják between 1977 and 2015. Finds from 35 sites altoghether were analyzed. Simultaneously, we attempted to classify the studied workshop for production of pipes at Spišský hrad castle in the context of finds (Vallašek 1983). The workshop is the oldest evidence of such activity in Slovakia. The collection of finds of pipes from Spiš was described in a formalized way according to the existent database record of M. Čurný from 2013 (Čurný/Šimčík/Bielich 2013).

The analyzed pipes can be chronologically divided into two groups. Pipes from the end of the $17^{\text {th }} / 18^{\text {th }}$ century and pipes from the $19^{\text {th }} / 20^{\text {th }}$ century. In the studied collection, mainly pipes from the $17^{\text {th }} / 18^{\text {th }}$ century occur. Some finds can be directly associated with the workshop at the Spišský hrad castle (Pl. III: 21, 22). The second numerous group of pipe finds comes from the $19^{\text {th }}$ century. It was possbile to determine the author only of some pipes due to their poor preservation. The bowl was the most sensitive part of the pipe which was exposed to the greatest changes in temperature during smoking and, thus, was more likely to be destroyed. Products of the then manufacturers were identified among marked pipes. The collection contains pipes from several manufacturers from Banská Štiavnica (A. Hőnig, L. Schmidtová and I. Mihalik) and several pipes come from imitators from the nearby town of Kremnica (E. Štiasny and W. Rothman). Another group of pipes occurring in Spiš comes from Malé Ozorovce (K. Azar) and was produced in the first decade of the $19^{\text {th }}$ century (Čaplovič 1997, 167). A fragment of a pipe from the end of the $19^{\text {th }}$ century classified among the pipes of CAFE type comes from Kremnica. Production of pipes in Eastern Hungry is represented by a fragment of a pipe from Miskolc; unfortunatelly, its author has not been identified. We were able to document also a local Spiš manufacturer Isak Svarc. This type occurs in Slovakia for the first time and is associated with the local production in Spiš in the $19^{\text {th }}$ century. Other unidentified products include strongly damaged pipes with MONART and SELMEC STEINGUT stamps. While the first is a completely unknown label, the second one is a quality mark of one of the workshops in Banská Štiavnica or its imitator.

The catalogue processing of the collection of pipes from the department of the IA SAS in Spišská Nová Ves could - from the aspect of archaeology - contribute to our knowledge of this interesting branch of production which was important for Slovakia mostly in the $19^{\text {th }}$ and $20^{\text {th }}$ centuries.

Fig. 1. Localization of the finds of pipes in Spiš (map M. Bartík and M. Bielik).

Fig. 2. Ceramic pipe from Žehra. Photo by M. Bielich.

Fig. 3. Spišský hrad castle. Selected pipes (Vallašek 1983).

Fig. 4. Spišský hrad castle. Selected pipes (Vallašek 1983).

Fig. 5. Spišský hrad castle. Mould for making pipes. Photo by M. Čurný.

Fig. 6. Spišský hrad castle - location of the pipe-making workshop (https://www.youtube.com/watch?v=GUF3d9AuD2U [6. 5. 2019]).

Pl. I. Finds of ceramic pipes from Spiš. 1-7 - Batizovce; 8 - Bijacovce; 9 - Dlhé Stráže; 10 - Gelnica; 11-13 - Hôrka-Ondrej; 14 - Hrabušice; 15 - Huncovce; 16-24 - Jánovce; 25-27 - Kežmarok; 28 - Kluknava; 29 - Kurimany; 30 - Letanovce. Photo by M. Bielich.

Pl. II. Finds of ceramic pipes from Spiš. 1-7 - Levoča; 8-10 - Lučivná; 11 - Malý Slavkov; 12 - Olcnava; 13 - Pol’anovce; 14-19 - Poprad; 20 - Smižany. Photo by M. Bielich.

Pl. III. Finds of ceramic pipes from Spiš. 1 - Smolník; 2 - neznáma lokalita zo Spiša; 3, 4-Spišská Belá; 5-11 - Spišská Teplica; 12-14 - Spišské Tomášovce; 15-19 - Spišské Vlachy; 20-24 - Spišský hrad. Photo by M. Bielich.

Pl. IV. Finds of ceramic pipes from Spiš. 1-16 - Spišská Nová Ves. Photo by M. Bielich.

Pl. V. Finds of ceramic pipes from Spiš. 1-17 - Spišská Nová Ves. Photo by M. Bielich.

Pl. VI. Finds of ceramic pipes from Spiš. 1 - Spišská Nová Ves; 2 - Spišský Štiavnik; 3-9 - Spišský Štvrtok; 10, 11 - Svit; 12 , 13 - Štrba; 14 - Šuňava; 15 - Vítkovce; 16 - Vlková; 17 - Výborná; 18-21 - Žehra. Photo by M. Bielich.

Tab. 1. Finds of pipes from Spiš. Deskriptors after M. Čurný, P. Šimčík and M. Bielich $(2013,90,91)$.

Mgr. Mário Bielich, PhD.

Archeologický ústav SAV

Akademická 2

SK - 94921 Nitra

mariobielich@seznam.cz
PhDr. Marán Soják, PhD.

Archeologický ústav SAV

Mlynská 6

SK - 05201 Spišská Nová Ves

sojak@ta3.sk 